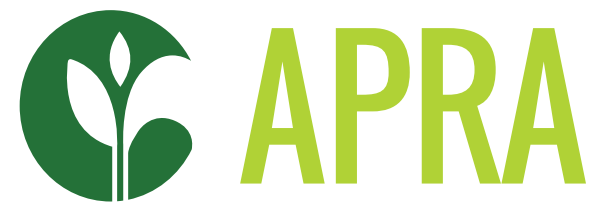

Agricultural Policy Research in Africa

\title{
DETERMINANTS OF SMALLHOLDER FARMERS' LIVELIHOOD TRAJECTORIES: EVIDENCE FROM RURAL MALAWI
}

Mirriam Matita, Ephraim Wadonda Chirwa, Stevier Kaiyatsa, Jacob Mazalale, Masautso Chimombo, Loveness Msofi Mgalamadzi and Blessings Chinsinga 


\section{CONTENTS}

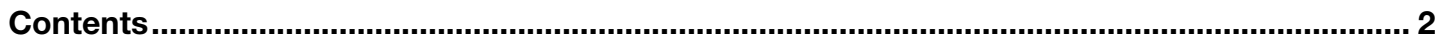

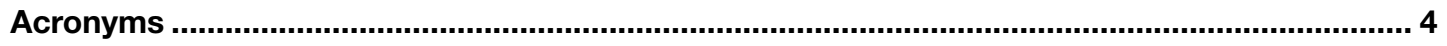

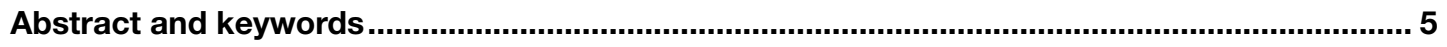

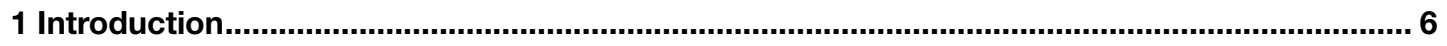

2 A review of relevant literature: livelihood trajectories ............................................................ 7

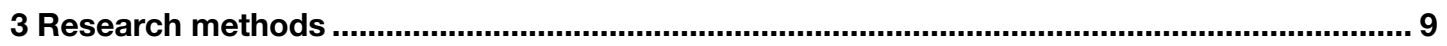

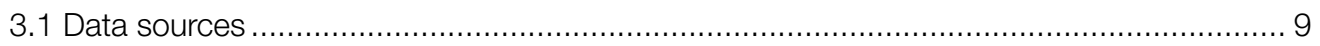

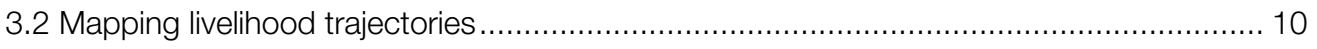

4 Estimation strategy

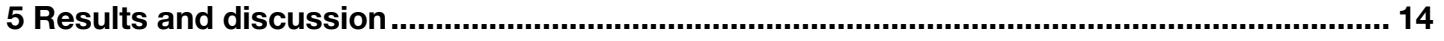

5.1 Characteristics of households in different livelihood trajectories.................................... 14

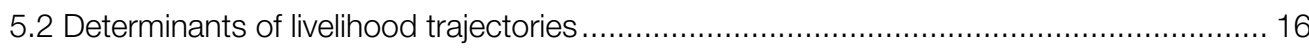

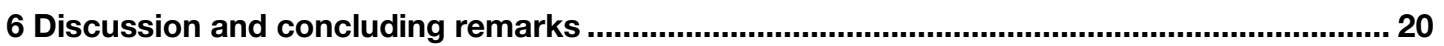

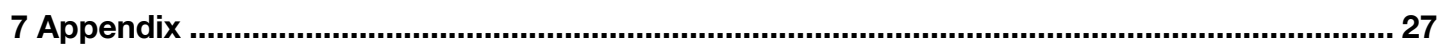

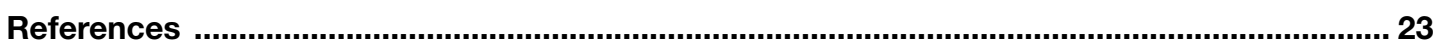

Tables

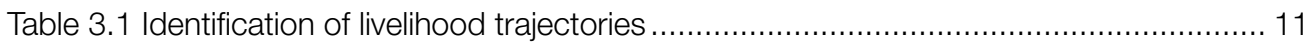

Table 5.2 Characteristics of households in different livelihood trajectories........................... 15

Table 5.3 Multinomial logit estimates of livelihood trajectories (coefficients and relative risk

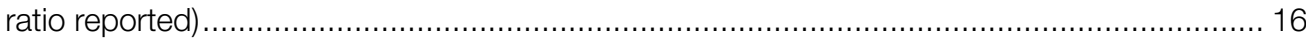

Table 5.4 Determinants of livelihood trajectories (marginal effects reported)......................... 18

Table A1 Comparing the baseline characteristics of original households (attrition table)......... 27

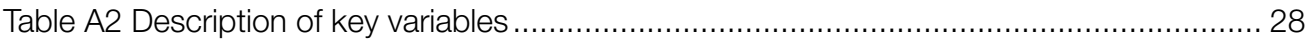

Table A3 Determinants of livelihood trajectories from parsimonious model

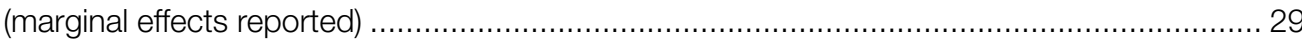

Figures

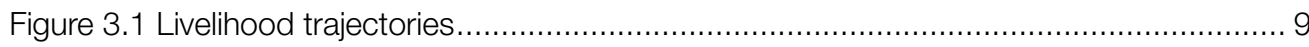

Figure A1 Map of study sites: Mchinji and Ntchisi districts in central Malawi........................ 27

Figure A2 Predictive marginal effects of commercialisation on livelihood trajectories with

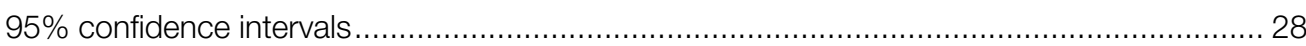

Figure A2(b) Predictive marginal effect of 2018 commercialisation level on livelihood

trajectories. 


\section{ACKNOWLEDGEMENTS}

The authors are grateful to the farmers in the study locations, the research assistants, and Agricultural Policy Research in Africa consortium members for making this research possible. We thank the three reviewers for their helpful comments that significantly strengthened this paper.

Mirriam Matita is a lecturer at the Lilongwe University of Agriculture and Natural Resources (LUANAR) but currently pursuing PhD studies with the University of Malawi, Department of Economics. The late Ephraim Wadonda Chirwa was Emeritus Professor of Economics at the University of Malawi. Stevier Kaiyatsa is an economist for the Government of Malawi. Jacob Mazalale is a lecturer at the University of Malawi in the Department of Economics. Masautso Chimombo is a sociologist at LUANAR in the Department of Extension. Loveness Msofi Mgalamadzi is an agribusiness and gender specialist at LUANAR in the Department of Extension. Blessings Chinsinga is a Professor of Political Economy at the Department of Political and Administrative Studies, University of Malawi.

This working paper is funded with UK aid from the UK government (Foreign, Commonwealth \& Development Office - FCDO, formerly DFID). The opinions are the authors and do not necessarily reflect the views or policies of IDS or the UK government. 


\section{ACRONYMS}

AGRA

APRA

CIMMYT

DFID

FCDO

FISP

GoM

HH

IIA

LMICs

LT

LUANAR

NSO

RRR

SOAS

TLU
Alliance for a Green Revolution in Africa

Agricultural Policy Research in Africa

International Maize and Wheat Improvement Center

Department for International Development

Foreign, Commonwealth and Development Office

Farm Input Subsidy Programme

Government of Malawi

household

independence of irrelevant alternatives

low- and middle-income countries

livelihood trajectory

Lilongwe University of Agriculture and Natural Resources

National Statistical Office

relative risk ratio

School of Oriental and African Studies

total livestock unit 


\section{ABSTRACT}

This paper examines determinants of livelihood trajectories using a longitudinal tracker quantitative survey of households over a span of ten years. Households were surveyed in rural Malawi in 2007 and followed up in 2018 to trace their livelihood pathways. Using a set of indicators including income sources diversification and participation in social assistance programmes, we placed households in different trajectories; namely: dropping out, stepping up, hanging in, and stepping in. A multinomial logit model was used to analyse factors explaining placement in a livelihood trajectory. We find that factors driving livelihood trajectories are not the same for farmers in different pathways. The stepping up of households is likely with increasing commercialisation and significant asset accumulation over time, though such households hire significantly less agricultural labour. Further, the stepping-in trajectory is constrained by initial landholding sizes but is more likely if a household has had experience with the cultivation of several different kinds of crops. We find that crop diversification reduces the chance of dropping out but increases the possibility of hanging in, implying that the blanket recommendation to farmers to diversify crop production may not attain the same benefits to all farmers. This may well be complemented with useful extension services, especially for new farming households. Overall, the study findings point to the complexity and the need for context-dependent development approaches to provide sustainable escapes from poverty.

Keywords: longitudinal study; livelihood trajectories; commercialisation; Malawi. 
Agriculture remains the main livelihood strategy for many people in low- and middle-income countries (LMICs). In Africa, 40 per cent of rural self-employment work time is in self-employed farming (AGRA 2019). Close to 70 per cent of Malawian farmers realise their incomes from agricultural crop sales (Chirwa and Zakeyo 2004). Transforming agriculture to address persistent low productivity traps among smallholders and increasing agribusiness orientation is therefore key for improving livelihoods, particularly given the evidence suggesting positive outcomes from farmers' engagement with markets (Jayne, Mather and Mghenyi 2010). Positive increases in incomes and reduced poverty from farmer commercialisation have been reported (Ogutu and Qaim 2019), as well as various degrees of food and nutrition security (Carletto, Corral and Guelfi 2017; Carletto et al. 2015; Radchenko and Corral 2018) among other outcomes. Hence, governments and partners invest in interventions that integrate smallholder farmers into markets. Such interventions include, but are not limited to, those aimed at increasing market surplus and strengthening marketing channels.

According to Dorward (2009) and Xu et al. (2015), households' livelihoods are in constant flux with changes over time in response to their level of productivity and incomes. Whilst some households may experience increased livelihood productivity and incomes, others fail to succeed or experience a decline (Dorward 2009; Mushongah 2009). For households engaged in agriculture, increasing agricultural productivity and extent of commercialisation may propel households on a development path that changes their livelihood activities and welfare outcomes. However, little is known about the role of smallholder agricultural commercialisation in observed livelihoods trajectories over time, let alone the factors that shape these pathways. This is mainly because longitudinal data is required to study such change processes (Bagchi et al. 1998; Mushongah and Scoones 2012; SabatesWheeler, Sabates and Devereux 2018).

Only a few studies have addressed the question of what determines livelihood trajectories using longitudinal data. For instance, Mushongah (2009), in his study of livelihood changes over 20 years in Zimbabwe, finds household engagement in low-return activities coupled with shocks and stresses resulted in many merely surviving in their livelihoods. Other studies (Adger et al. 2002; Babulo et al. 2008; Brown et al. 2006; Pritchard, Vicol and Jones 2017) have identified livelihood strategies adopted by households in different contexts but fall short of explicitly linking livelihood trajectories to the role of agricultural commercialisation over time. There have been, however, studies on agricultural commercialisation in different contexts focusing on, for instance, the determinants of commercialisation and its impacts (Abdullah et al. 2019; Carletto et al. 2017; Ogutu and Qaim 2019) or the roles of value chain actors in smallholder commercialisation (Bernard and Spielman 2009; Kilelu, Klerkx and Leeuwis 2017).

To address this knowledge gap, we attempt to operationalise the development framework proposed by Dorward (2009) and later modified by Mushongah (2009) using quantitative methods to investigate the determinants of livelihood trajectories in the context of agricultural commercialisation. Specifically, we assess how agricultural commercialisation, defined in this study by the proportion of crop sales out of total production, influences livelihood trajectories. We hypothesise that households that are more commercialised are more likely to expand their investments in agriculture and/or take up livelihoods outside of agriculture. Further, different household characteristics influence the prevailing livelihood trajectory differently with initial conditions such as the asset-holding of the household being important in livelihood pathways. A knowledge of those factors that influence each livelihood trajectory is important to inform policies that target different segments of society to avoid a 'one-size-fits-all' strategy. This paper draws on primary evidence from household surveys conducted over a span of ten years in Mchinji and Ntchisi districts, in rural Malawi.

The rest of the paper is structured as follows. Section 2 presents the review of relevant literature on livelihood trajectories. Section 3 details the research methods, including how the study maps different livelihood trajectories. In Section 4, the estimation strategy that was used is discussed. Section 5 presents the econometric results, and Section 6 concludes. 


\section{A REVIEW OF RELEVANT LITERATURE: LIVELIHOOD TRAJECTORIES}

Within the development discourse, the sustainable livelihoods approach has helped to bring to the fore the complexities of how people secure the necessities of life through their livelihoods. Livelihoods encompass how people use their capabilities and means of living to secure food, income, and assets (McLean 2015). Using these resources, households may adopt different livelihood strategies or their combinations such as farm or non-farm, diversification, migration, remittances, wage employment, or self-employment among others in pursuit of their aspirations (Adger et al. 2002; Babulo et al. 2008; Brown et al. 2006; Jansen et al. 2006; Mushongah and Scoones 2012). The realised outcomes will depend on the context bordering on the social and institutional factors, either formal or informal, that govern the access, use, and control of resources (Scoones 1998).

Studies have therefore employed this approach to study trends in livelihoods and to identify gaps requiring support to improve the conditions in which people live. This is done by examining changes in various capitals, assets, and incomes that people have and earn from their livelihoods over time (Pritchard et al. 2017). However, the approach has been criticised for lacking flexibility and ignoring power relations, and particularly failing to provide answers about the process of livelihood change (Mushongah 2009; Pritchard et al. 2017). In turn, different facets have been added to better understand the longitudinal change of livelihoods within the context of culture, gender, and social differentiation (Scoones 2009).

The complexity of studying fluid livelihoods remains with others such as Bagchi et al. (1998), who argue that livelihoods may be stressed and become vulnerable such that their resilience is tested, and hence requiring an understanding of how households adapt their livelihoods as their environment changes. In their paper, Bagchi et al. (1998) conclude that there are conceptual and methodological challenges inherent in operationalising studies of livelihood change.

In response, authors such as Dorward (2009), have construed development as a process of change involving three steps of livelihood trajectories over time. Herein, a trajectory means 'a path through time' and 'livelihood trajectories' refers to 'the consequences of the changing ways in which individuals construct a livelihood over time' (Bagchi et al. 1998: 457). The assumption in this schema is that households possess an initial stock of assets or capitals that they use to drive their livelihoods, and depending on their outcomes, they get positioned into different livelihood landscapes over time (Pritchard et al. 2017). The steps include stepping up of livelihood activities through investments that expand existing assets and increase their productivity; stepping out into alternative or new ventures that promise better return; and hanging in their livelihoods to merely survive, maintain, and protect current levels of wealth. In applying this framework in Zimbabwe, Mushongah (2009) added the category of dropping out to characterise destitute households, with no stable livelihoods, that rely on external support such as social protection programmes.

As we will explain in detail below, we applied this framework in this paper following households preoccupied with agricultural livelihoods. However, we expand the framework to include the category of stepping in to account for households that were initially (at baseline) not in agriculture, our livelihood of interest, but who in subsequent surveys had reported agricultural incomes. This is consistent with the observation by Pritchard et al. (2017) that the Dorward (2009) framework does not recognise that livelihoods' starting points may be different for different households.

Previous studies have approached the categorisation of households into livelihood strategies in different ways. For instance, Mushongah and Scoones (2012), using the Dorward (2009) framework, employed participatory wealth ranking in Zimbabwe to categorise households into different livelihoods - richer being number one and poorer being number four. Household characteristics in the different ranks were found consistent with survey data and in-depth biographical interviews on average. Likewise Pritchard et al. (2017: 52), studying the effect of land ownership on a livelihoods pathway, applied the Dorward (2009) formulation to categorise households into those 'going backwards/muddling through' defined by food insecurity, 'hanging in' for those without any viable existence, and 'getting ahead' signified by investments in land and education. 
Relatedly, Sabates-Wheeler, Sabates, and Devereux (2018) measured sustainable livelihood change in the context of social protection programmes in Rwanda, and categorised households into improvers, decliners, crashing out, and late improvers, using a combination of indicators on food security and basic needs, total livestock units, and asset index. Others such as Xu et al. (2015) used cross-sectional data to categorise households into livelihood strategies based on share of agriculture income in China: less than 20 per cent were considered less dependent on agriculture; 2040 per cent were considered moderately dependent; 40-60 per cent were highly dependent; and more than 60 per cent were considered to be extremely dependent on agriculture.

The fact that there is no global justification for the specific cut-off points is a problem also inherent in studies on asset thresholds, as Carter and Barrett (2006) explain. Further, literature on asset approaches including asset accumulation, thresholds, and asset poverty traps has been used to measure changes in livelihoods over time (Carter and Barrett 2006; Giesbert and Schindler 2010; Orr, Mwale and Saiti-Chitsonga 2009). Therefore, the methods adopted in this study mirrors these used in different contexts. 


\section{RESEARCH METHODS}

\subsection{Data sources}

Two-period panel data are available to assess the different household characteristics associated with individual household livelihood trajectories. The first wave of data was collected in 2006/07 as part of the Farm Input Subsidy Programme (FISP) evaluation by the School of Oriental and African Studies (SOAS), London, UK. We used a subset of the data for Mchinji and Ntchisi districts in central Malawi (Appendix Figure A1) with 240 households. The districts were selected because they produce most of the groundnuts in Malawi, a cash crop that has been key in the recent past but also riddled with aflatoxin management issues (Matita et al. 2018). We tracked the 240 households along with their branching-off members in 2018 after a ten-year period to determine changes in their livelihoods and outcomes.
We managed to interview 210 of the original households, representing an attrition rate of 12.5 per cent. This attrition compares favourably with other longitudinal studies (Thomas et al. 2012). Most attrite cases were a result of death and failure to trace households, especially in new locations. There were no significant differences between households that attrite and those with complete information at baseline except for household size. Households with complete information had on average an equivalent of five adults relative to 3.7 adults in attrite households ( $p=0.0011)$, as presented in Appendix Table A1. Since we were also interested in how individual members' livelihoods are influenced by agriculture and its commercialisation, we also tracked household members who had 'branched out' of the original households - of which about 303 households were successfully traced and interviewed within and outside study districts.

\section{Figure 3.1 Livelihood trajectories}

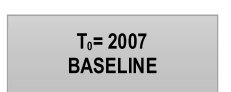
BASELINE

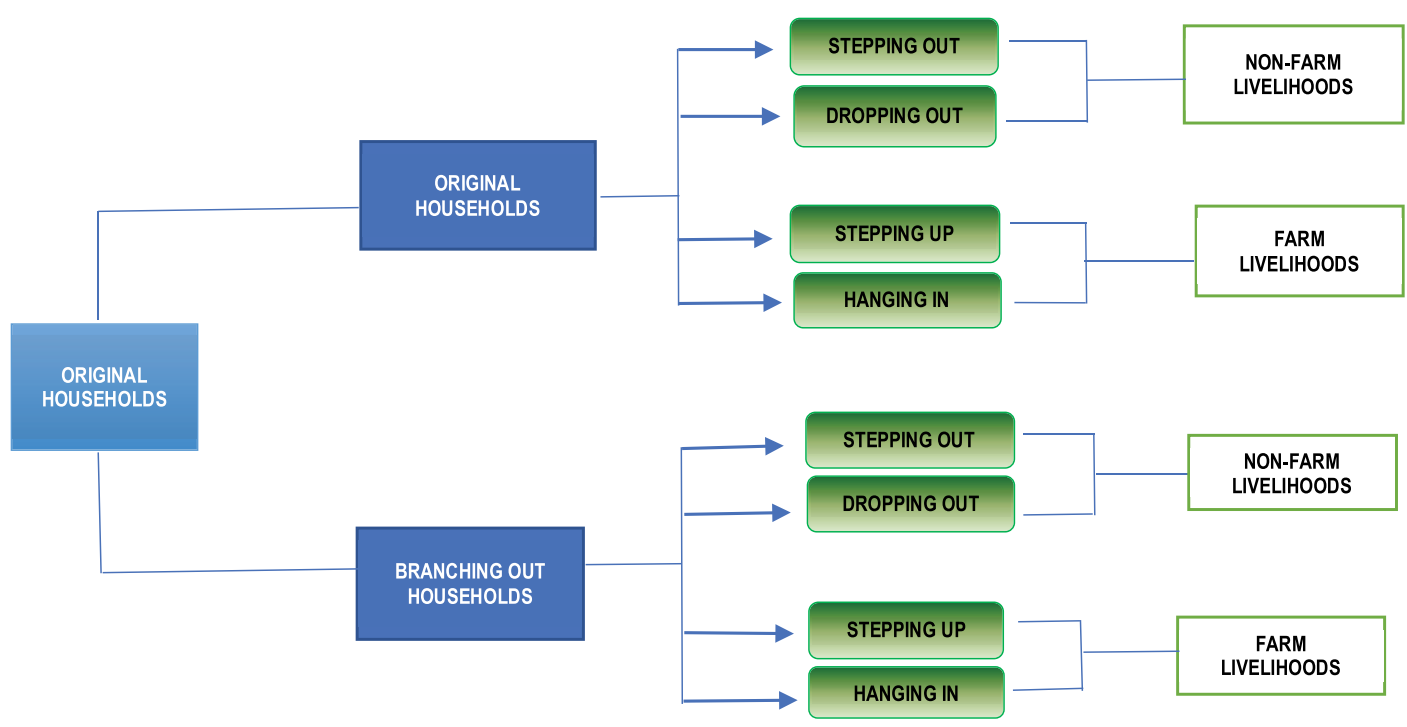

\section{LIVELIHOOD TRAJECTORIES}

Source: Authors' own 


\subsection{Mapping livelihood trajectories}

Figure 3.1 presents how this study undertaken in Malawi mapped into the framework and operationalised the livelihood trajectories. At $t_{0}$, which is our baseline, we obtained data collected in 2007 by SOAS as part of the Malawi Agricultural Input Subsidy Programme evaluation study. We tracked households and their members at $t_{1}$ in 2018 as part of the Agricultural Policy Research in Africa programme, studying pathways to smallholder agriculture commercialisation. In 2018, we interviewed the head of the household or their spouse who was registered in 2007 as part of the original household. For household members in 2007, we only interviewed members aged above 18 years that had since moved on to form their own households and pursue independent livelihood activities; we are calling these branching-off households.

Using the differences in main livelihood characteristics at $t_{1}$ and $t_{0}$, we mapped the households into different livelihood trajectories. In this assessment, we considered both farm- or non-farm-related livelihoods, given the literature suggesting households tend to diversify their income sources (Barrett, Reardon and Webb 2001; Ellis, Kutengule and Nyasulu 2003; Mushongah and Scoones 2012). In this case, wealthier households tended to diversify their income sources as seen in a positive correlation between the diversity of income sources and durable assets $(p=0.0001)$ or the fact that poor households were negatively associated with diverse income sources $(p=0.0417)$. As alluded to above, four trajectories are expected where households move from farm livelihoods into non-farm livelihoods they step out and drop out of agriculture. Alternatively, households may remain in farm livelihoods and step up their agricultural activities or just hang in agricultural enterprises as a survival mechanism.

To classify the households into livelihood trajectories, we used the identification strategy detailed in Table 3.1. Our data show that households obtained income from various sources including agricultural sales, wage labour (commonly called ganyu), salary employment, businesses, and other income sources such as social cash transfers and remittances. We started with a strict definition of the livelihood trajectories shown in Panel A. We first looked at households' main income sources at baseline in 2007 and then in 2018. We calculated the share of different income sources to total household income for each year. An income source with the highest share was regarded as the main income source for the household in the reference year.

The starting point for all households was agriculture being their main source of income. Therefore, we singled out for further consideration households whose maximum share of income was from agriculture. This means, using a strict definition, that households that never reported income from agricultural output sales in 2007 were not classified into any livelihood trajectories. However, as explained below, this was later revised in our modifications as stepping-in households. We compared the main income source in 2007 and 2018 to place a household in a trajectory. However, the procedure in Panel A only allowed us to classify 16 per cent of the original 210 households. We therefore used it only as a starting point and made modifications that increased our classified sample.

Several modifications were made to the identification strategy upon iterative discussions and reflection by the team of researchers and review of relevant literature (Carter and Barrett 2006; Mushongah and Scoones 2012; Orr et al. 2009; Sabates-Wheeler et al. 2018; Xu et al. 2015). The modified identification strategy is presented in Table 3.1, Panel B. Instead of just considering that a household's main source of income is agriculture in 2007 or 2018 , we resorted to using the proportional change in agricultural income to capture growth over the two periods. The proportional change was calculated as $\left(\mathrm{Yt}_{1}-\mathrm{Yt}_{0}\right) / \mathrm{yt}_{0}{ }^{*} 100$ where $\mathrm{Y}$ is share in agriculture sales incomes. We lost 108 of the original households or 153 branching-off households' observations because they had either a missing value or zero reported agriculture income in one of the reference years.

We also considered whether a household diversified or expanded its agricultural enterprise. We generated the total number of income sources from which a household received income in each year. The minimum was zero, representing households that did not receive income from any sources and the maximum was from five sources. On average, households reported approximately two sources of income. Households with diverse income sources were defined as ones whose total number of income sources in 2018 was greater than in 2007. Among the original households, 36 per cent were on average diverse in their income sources, that is, they reported more income sources in 2018 relative to 2007. For branching-off households, about 45 per cent had on average diverse income sources. Diversification of income sources is widespread among smallholder farmers in many African contexts as a response to expected or actual risk exposure (Barrett et al. 2001) as well as being a strategy to maximise complementarities across ventures for positive outcomes in food security and poverty (Zereyesus et al. 2017).

An expansion of investments in agricultural enterprises was gauged by the proportional change in agricultural income received by the household. Households that 
Table 3.1 Identification of livelihood trajectories

\begin{tabular}{|c|c|c|c|c|c|}
\hline \multirow[t]{2}{*}{ No. } & \multirow[t]{2}{*}{ Trajectory } & \multirow{2}{*}{$\begin{array}{l}\text { Panel A } \\
\text { Strict identification }\end{array}$} & \multicolumn{3}{|l|}{ Panel B } \\
\hline & & & Modified identification & $\begin{array}{l}\text { No. of } \\
\text { original } \\
\text { HHs }\end{array}$ & $\begin{array}{l}\text { No. of } \\
\text { branching- } \\
\text { off HHs }\end{array}$ \\
\hline 1 & Stepping out & $\begin{array}{l}\text { Households whose main } \\
\text { source of income was } \\
\text { agricultural sales in } 2007 \\
\text { but it is non-farm sources } \\
\text { of income in } 2018 \text {. }\end{array}$ & $\begin{array}{l}\text { Households whose greater } \\
\text { proportion of income was } \\
\text { agricultural sales in } 2007 \text { but it } \\
\text { is non-farm sources of income } \\
\text { in 2018; and they rely on salary } \\
\text { or business income as their } \\
\text { main sources. }\end{array}$ & 3 & 10 \\
\hline 2 & Dropping out & $\begin{array}{l}\text { Households whose main } \\
\text { source of income was } \\
\text { agricultural sales in } 2007 \\
\text { but now they must rely } \\
\text { on social cash transfers/ } \\
\text { assistance to survive. }\end{array}$ & $\begin{array}{l}\text { Households whose main source } \\
\text { of income was agricultural sales } \\
\text { in } 2007 \text { but now (2018) they } \\
\text { rely on wage income (ganyu) } \\
\text { or other income sources } \\
\text { [includes social assistance and } \\
\text { remittances] or are on social } \\
\text { cash transfer programmes. }\end{array}$ & 25 & 22 \\
\hline 3 & Stepping up & $\begin{array}{l}\text { Households whose main } \\
\text { source of income was } \\
\text { agricultural sales in } 2007 \\
\text { but who have expanded } \\
\text { and diversified, and their } \\
\text { main source of income } \\
\text { remains agricultural sales } \\
\text { in } 2018 \text {. }\end{array}$ & $\begin{array}{l}\text { Households whose main source } \\
\text { of income was agricultural sales } \\
\text { in } 2007 \text { but have expanded and } \\
\text { diversified; and their main source } \\
\text { of income remains agricultural } \\
\text { sales in } 2018 \text {. Their calculated } \\
\text { farm income change is greater } \\
\text { than or equal to } 25 \text { per cent. }\end{array}$ & 30 & 33 \\
\hline 4 & Hanging in & $\begin{array}{l}\text { Households whose main } \\
\text { source of income was } \\
\text { agricultural sales in } 2007 \\
\text { but have not expanded/ } \\
\text { diversified and their } \\
\text { main source of income } \\
\text { remains agricultural sales } \\
\text { in } 2018 \text { but are not on } \\
\text { social cash transfers. }\end{array}$ & $\begin{array}{l}\text { Households whose main } \\
\text { source of income was agricul- } \\
\text { tural sales in } 2007 \text { but have not } \\
\text { expanded/diversified and their } \\
\text { main source of income remains } \\
\text { agricultural sales in } 2018 \text { but } \\
\text { are not on social cash transfers. } \\
\text { Their calculated farm income } \\
\text { change is less than } 25 \text { per cent. }\end{array}$ & 55 & 67 \\
\hline 5 & Stepping in & $\begin{array}{l}\text { Not considered because } \\
\text { each household starting } \\
\text { point is agricultural } \\
\text { income. }\end{array}$ & $\begin{array}{l}\text { Households whose agricultural } \\
\text { sales income in } 2007 \text { was zero; } \\
\text { their main source of income } \\
\text { was not agricultural sales in } \\
2007 \text { but now (2018), they get } \\
\text { income from agricultural sales. } \\
\text { They are not on a social cash } \\
\text { transfer programme. }\end{array}$ & 60 & 78 \\
\hline & & & & 173 & 210 \\
\hline
\end{tabular}

Notes: Main income source is determined by proportional change in the shares of income over the two study years. $\mathrm{HH}=$ household.

Source: Authors' own 
expand their investments in productive agricultural assets are expected to increase their returns in agriculture, ceteris paribus. Such investments can be in livestock production, land, soil conservation, machinery, and irrigation, among others. Several scenarios were possible; a negative change in farm income (42 cases out of the original $\mathrm{HHs}$ ); no change in farm income between the two reference years (21 cases out of the original $\mathrm{HHs}$ ); a change in farm income that is greater than zero (39 cases out of the original $\mathrm{HHs}$ ).

We also added a fifth livelihood trajectory of 'stepping in'. This was to cater for households that were not engaged in agriculture in 2007 but reported agricultural income in 2018. We thus took the zero income values in 2007 as a valid representation of household agricultural income at that time. Using this procedure, we were able to map 84 per cent of the original households into some livelihood trajectory. Only 13 households were found to have stepped out of agriculture; these were removed in subsequent econometric analysis due to the small sample size. Suffice to say, these are households earning income away from agriculture. A similar procedure was followed to classify the livelihood trajectories of branching-off households. We used the 2007 values of the original households as the baseline values for branching-off households. 


\section{ESTIMATION STRATEGY}

We use a multinomial logit model to estimate the determinants of livelihood trajectories consistent with the literature (Brown, Ortiz-Nu and Taylor 2011; Paudel, Khatri and Pant 2018; Rahman and Akter 2014; Wooldridge 2011). We estimate the following relationship in equation (1) where $y$ is the outcome of interest, that is, the livelihood trajectory. The probability that household $i$ falls in livelihood trajectory $j$ which takes values of $1, \ldots, 4$ representing households dropping out, stepping up, hanging in, and stepping in agriculture is presented as follows:

$$
p(y)_{i j}=\frac{\exp \left(w_{i}^{\prime} y_{j}\right)}{\sum \exp \left(w_{i}^{\prime} y_{k}\right)}
$$

\section{Equation 1}

$w$ tis the vector of exogenous factors that affect livelihood trajectories. $y_{k}$ is the vector of parameters corresponding to the $k t h$ option. We categorise these factors into household characteristics (age, sex, marital status of household head, maximum years of education in the household, household size defined by adult equivalent scales); economic and household assets (livestock units owned, value of durable assets, and land); social infrastructure (participation by any household member in farmer clubs/organisation, agricultural extension agent residing in village); beneficiary status of the FISP; district effects (residence in Mchinji District); and household crop commercialisation measured by the proportion of total crop sales out of household production, where the higher the index, the more commercialised the household is. The analysis uses indicators obtained in 2007 as well in order to capture the initial conditions that matter for livelihood paths. A distinction is also made between original households and branching-off households. A detailed description of the variables is included in Appendix Table A2. The selection of these variables is based on the literature that indicates they affect household livelihood strategies (Banerjee et al. 2015; Ellis 2008; Mushongah and Scoones 2012; Pritchard et al. 2017; Rahman and Akter 2014; SabatesWheeler et al. 2018). 


\subsection{Characteristics of households in different livelihood trajectoriesa}

Table 5.2 describes the characteristics of households in different livelihood trajectories. We used Bonferroni's adjustment to conduct pairwise correlation analysis for the multiple livelihood trajectories. Where the obtained means are significantly different, we indicate otherwise - for most cases, the means were equal. Overall, 87 per cent of households are headed by males, with an average age of 41 years in 2018. The maximum years of education in a household is eight which corresponds to primary education. Relatively speaking, those stepping in have significantly higher (nine) years of schooling compared to stepping-up households who have seven years of schooling.

In this study, only 22 per cent of the sample completed eight years of primary education, 17 per cent secondary education, and less than 3 per cent beyond secondary education. This is consistent with national figures portraying that agriculture attracts relatively less educated people. For instance, a review of Labour Force Survey data shows that 68 per cent of people that work on the farm or on an agricultural plot did not complete any education, 27 per cent completed primary education, while only 5 per cent completed secondary education (NSO 2014). Overall, the average household size defined by adult equivalents has risen significantly from four in 2007 to five in 2018 .

All households except those dropping out of agriculture sold at least half of what was produced in 2018, with an average of 62 per cent. This is a rise from 30 per cent estimated for 2007. The trend shows that irrespective of livelihood trajectory, households sold some of their agricultural produce. Using Bonferroni's adjustment to conduct pairwise correlation analysis, significant differences at the 5 per cent level were observed in marketed output between drop-out households and the rest of the livelihood trajectories which is expected, given that dropping-out households are moving away from agricultural livelihoods.

The data show increasing access to any extension services in 2018, from a reported proportion of 23 per cent to 88 per cent. This could be attributed to the pluralistic extension policy followed since 2000 that has seen a rise in the number of agricultural extension providers apart from the government machinery. Similarly, we note a significant increase in the number of crops cultivated by households. Whilst in the past an average of two crops were cultivated, households in 2018 cultivated three crops. There are significant differences in all trajectories compared to the droppingout category. Diversification of crop production is among priorities in the agricultural sector over the years, and is evident in the expansion of improved seeds available under the Malawi FISP since 2009 to include various legumes apart from maize seeds. However, receipt of subsidised coupons under FISP has declined over the two periods, from an average 55 per cent to 8 per cent of the sample. This is consistent with a general decline in FISP programme beneficiary farmers, from about 1.3 million in 2005/06 to 900,000 in recent years (Logistics Unit 2017).

The hiring of agricultural labour is reported by 30 per cent of the whole sample in 2018 compared with 19 per cent in 2007. At least 30 per cent of hanging-in and stepping-in households reported engaging hired labour in 2018, reflecting increasing agricultural labour marketing. Among the whole sample, 14 per cent of households have at least one member that participates in farmer club activities and a greater proportion (20 per cent) is reported for stepping-in households, possibly being new farmers who are keen to learn and build networks that can benefit their agriculture enterprise. District-level differences exist in a proportion of households in various livelihood trajectories. There are more households hanging in in Mchinji (57 per cent) relative to those stepping up (32 per cent) than in Ntchisi District, which is statistically significant. 
Table 5.2 Characteristics of households in different livelihood trajectories

\begin{tabular}{|c|c|c|c|c|c|c|c|c|c|c|c|c|c|}
\hline \multirow[b]{2}{*}{ Variables } & \multicolumn{4}{|c|}{ Whole sample } & \multicolumn{2}{|c|}{ Drop out } & \multicolumn{2}{|c|}{ Step up } & \multicolumn{2}{|c|}{ Hang in } & \multicolumn{2}{|c|}{ Step in } & \multirow{2}{*}{$\begin{array}{l}\text { Wald } \\
\text { test }\end{array}$} \\
\hline & Mean & SD & Min & Max & Mean & SD & Mean & SD & Mean & SD & Mean & SD & \\
\hline Male-headed household $2018(0 / 1)$ & 0.87 & 0.34 & 0 & 1 & 0.76 & 0.43 & 0.90 & 0.30 & 0.90 & 0.30 & 0.86 & 0.35 & 4.57 \\
\hline Age household head in years 2018 & 41.1 & 16.5 & 17 & 89 & 46.02 & 20.2 & 40.4 & 17.3 & 41.2 & 16.0 & 39.8 & 15.1 & 3.52 \\
\hline Maximum years of education 2018 & 8.30 & 3.48 & 0 & 23 & 7.63 & 4.09 & 7.27 & 2.31 & 8.50 & 3.73 & 8.78 & 3.41 & $15.13^{\star \star \star}$ \\
\hline Adult equivalent scales 2018 & 4.25 & 2.42 & 1 & 15 & 4.11 & 2.20 & 4.34 & 1.83 & 4.21 & 1.88 & 4.29 & 3.06 & 0.38 \\
\hline Adult equivalent scales 2007 & 5.04 & 2.14 & 1 & 13 & 5.11 & 2.30 & 4.75 & 1.97 & 5.23 & 2.18 & 4.99 & 2.15 & 2.34 \\
\hline Commercialisation index 2018 & 62.4 & 32.7 & 0 & 100 & 33.91 & 35.1 & 68.99 & 26.3 & 63.9 & 33.0 & 66.7 & 30.1 & $33.31^{\star \star \star}$ \\
\hline Commercialisation index 2007 & 29.7 & 40.6 & 0 & 100 & 19.58 & 34.3 & 39.9 & 44.7 & 30.7 & 39.5 & 27.4 & 40.7 & $7.08^{*}$ \\
\hline Hired agricultural labour 2018 (0/1) & 0.30 & 0.46 & 0 & 1 & 0.24 & 0.43 & 0.18 & 0.39 & 0.32 & 0.47 & 0.35 & 0.48 & $7.85^{\star \star}$ \\
\hline Hired agricultural labour 2007 (0/1) & 0.19 & 0.39 & 0 & 1 & 0.32 & 0.47 & 0.15 & 0.36 & 0.20 & 0.40 & 0.15 & 0.36 & 5.18 \\
\hline Total livestock units 2018 & 0.63 & 1.56 & 0 & 18 & 0.18 & 0.41 & 0.69 & 1.90 & 0.58 & 1.38 & 0.77 & 1.74 & $20.43^{\star * \star}$ \\
\hline Total livestock units 2007 & 0.65 & 1.85 & 0 & 22 & 0.52 & 1.01 & 0.48 & 0.57 & 0.78 & 2.20 & 0.65 & 2.08 & 2.45 \\
\hline Log land (hectares) 2018 & 0.87 & 0.73 & 0 & 4 & 0.66 & 0.45 & 0.79 & 0.38 & 0.81 & 0.62 & 1.01 & 0.94 & $11.06^{\star \star \star}$ \\
\hline Log land (hectares) 2007 & 1.05 & 0.47 & 0 & 3 & 1.04 & 0.49 & 1.00 & 0.37 & 1.13 & 0.51 & 1.00 & 0.45 & 5.56 \\
\hline Number of cultivated crops 2018 & 3.11 & 1.65 & 0 & 11 & 2.05 & 1.34 & 3.08 & 1.55 & 3.25 & 1.77 & 3.32 & 1.57 & $28.34^{\star \star \star}$ \\
\hline Number of cultivated crops 2007 & 2.36 & 1.17 & 1 & 6 & 2.39 & 1.34 & 2.23 & 0.98 & 2.42 & 1.28 & 2.37 & 1.11 & 1.22 \\
\hline $\begin{array}{l}\text { Log value of durable asset (MK) } \\
2018\end{array}$ & 3.59 & 1.95 & 0 & 10 & 2.88 & 1.61 & 3.36 & 1.81 & 3.53 & 1.62 & 3.95 & 2.28 & $11.91^{\star \star \star}$ \\
\hline $\begin{array}{l}\text { Log value of durable asset (MK) } \\
2007\end{array}$ & 1.87 & 1.13 & 0 & 7 & 1.73 & 1.14 & 1.88 & 0.89 & 1.82 & 1.11 & 1.94 & 1.24 & 1.33 \\
\hline FISP beneficiary $2018(0 / 1)$ & 0.08 & 0.28 & 0 & 1 & 0.02 & 0.16 & 0.05 & 0.22 & 0.10 & 0.30 & 0.10 & 0.30 & $6.68^{\star}$ \\
\hline FISP beneficiary 2007 (0/1) & 0.55 & 0.50 & 0 & 1 & 0.59 & 0.50 & 0.48 & 0.50 & 0.61 & 0.49 & 0.53 & 0.50 & 3.35 \\
\hline Received any credit 2018 (0/1) & 0.12 & 0.32 & 0 & 1 & 0.05 & 0.22 & 0.08 & 0.28 & 0.10 & 0.30 & 0.17 & 0.37 & $6.73^{\star}$ \\
\hline Received any credit 2007 (0/1) & 0.25 & 0.43 & 0 & 1 & 0.24 & 0.43 & 0.22 & 0.42 & 0.29 & 0.45 & 0.23 & 0.42 & 1.51 \\
\hline $\begin{array}{l}\text { HH received any extension } 2018 \\
(0 / 1)\end{array}$ & 0.88 & 0.33 & 0 & 1 & 0.83 & 0.38 & 0.90 & 0.30 & 0.90 & 0.30 & 0.86 & 0.34 & 1.74 \\
\hline $\begin{array}{l}\text { HH received any extension } 2007 \\
(0 / 1)\end{array}$ & 0.23 & 0.42 & 0 & 1 & 0.22 & 0.42 & 0.27 & 0.45 & 0.24 & 0.43 & 0.22 & 0.41 & 0.63 \\
\hline $\begin{array}{l}\text { HH had member of farmer club } \\
2018(0 / 1)\end{array}$ & 0.14 & 0.35 & 0 & 1 & 0.02 & 0.16 & 0.10 & 0.30 & 0.14 & 0.34 & 0.20 & 0.40 & $19.7^{\star \star \star}$ \\
\hline Residence in Mchinji (0/1) & 0.46 & 0.50 & 0 & 1 & 0.41 & 0.50 & 0.32 & 0.47 & 0.57 & 0.50 & 0.43 & 0.50 & $11.85^{\star \star \star}$ \\
\hline Original household $(0 / 1)$ & 0.44 & 0.50 & 0 & 1 & 0.49 & 0.51 & 0.45 & 0.50 & 0.43 & 0.50 & 0.44 & 0.50 & 0.40 \\
\hline Number of observations & \multicolumn{4}{|l|}{358} & \multicolumn{2}{|l|}{41} & \multicolumn{2}{|l|}{60} & \multicolumn{2}{|l|}{118} & \multicolumn{2}{|l|}{139} & \\
\hline
\end{tabular}

Notes: Table 5.2 presents the characteristics of households in different livelihood trajectories. Households in the stepping-out category were removed from the analysis due to the small sample size. The value of durable assets is MKW '000. 1 US\$ = MKW 732 (2018); MKW = 140 (2007) (source: Reserve Bank of Malawi²). HH = household. $(0 / 1)$ indicates a dichotomous variable equal to 1 for the included category, otherwise equal to 0 for the base category. SD = standard deviation. The Wald test is based on a multivariate test for group differences in means across all livelihood trajectories with a heterogeneous option. The statistic presented in the Wald test follows a Chi-squared distribution. * $p<0.10$, ${ }^{\star \star} p<0.05$, ${ }^{\star \star \star} p<0.01$.

Source: Authors' own. 
Table 5.3 Multinomial logit estimates of livelihood trajectories (coefficients and relative risk ratio reported)

\begin{tabular}{|c|c|c|c|c|c|c|c|c|c|}
\hline \multirow[b]{2}{*}{ Variables } & \multicolumn{3}{|c|}{ Dropping out } & \multicolumn{3}{|c|}{ Stepping up } & \multicolumn{3}{|c|}{ Hanging in } \\
\hline & Coef. & SE & RRR & Coef. & SE & RRR & Coef. & SE & RRR \\
\hline Male-headed household (0/1) & -0.643 & $(0.754)$ & 0.526 & -0.411 & (0.698) & 0.663 & 0.400 & (0.559) & 1.492 \\
\hline Age in years of $\mathrm{HH}$ head & 0.032 & $(0.020)$ & 1.032 & 0.002 & $(0.017)$ & 1.002 & 0.011 & $(0.014)$ & 1.011 \\
\hline $\mathrm{HH}$ is married $(\mathrm{O} / 1)$ & 0.551 & $(0.895)$ & 1.734 & $1.702^{\star}$ & $(0.980)$ & 5.484 & 0.659 & $(0.648)$ & 1.932 \\
\hline Max. years of $\mathrm{HH}$ education & -0.081 & $(0.067)$ & 0.922 & $-0.205^{\star \star \star}$ & $(0.067)$ & 0.814 & 0.003 & $(0.047)$ & 1.003 \\
\hline Adult equivalents 2018 & 0.149 & $(0.140)$ & 1.161 & 0.064 & $(0.095)$ & 1.066 & -0.034 & $(0.074)$ & 0.966 \\
\hline Adult equivalents 2007 & 0.094 & $(0.127)$ & 1.099 & -0.010 & $(0.105)$ & 0.990 & 0.065 & (0.079) & 1.068 \\
\hline Hired labour 2018 (0/1) & 0.492 & $(0.584)$ & 1.635 & $-0.902^{*}$ & $(0.497)$ & 0.406 & 0.242 & (0.345) & 1.274 \\
\hline Hired labour 2007 (0/1) & $1.374^{\star \star}$ & (0.588) & 3.950 & 0.493 & $(0.517)$ & 1.638 & 0.607 & (0.398) & 1.834 \\
\hline Total livestock units 2018 & $-1.105^{\star}$ & (0.598) & 0.331 & 0.122 & $(0.122)$ & 1.129 & -0.100 & $(0.106)$ & 0.905 \\
\hline Total livestock units 2007 & 0.091 & $(0.236)$ & 1.095 & -0.218 & $(0.216)$ & 0.804 & 0.121 & (0.089) & 1.129 \\
\hline Log land 2018 & 0.281 & (0.619) & 1.324 & -0.179 & (0.399) & 0.836 & -0.358 & $(0.290)$ & 0.699 \\
\hline Log land 2007 & 0.319 & (0.636) & 1.376 & 0.566 & (0.539) & 1.761 & $0.675^{\star}$ & (0.366) & 1.963 \\
\hline No. of crops cultivated 2018 & $-0.640^{\star \star \star}$ & $(0.205)$ & 0.527 & -0.158 & $(0.134)$ & 0.854 & 0.077 & $(0.101)$ & 1.080 \\
\hline No. of crops cultivated 2007 & -0.048 & $(0.237)$ & 0.953 & $-0.606^{* \star}$ & $(0.251)$ & 0.546 & $-0.273^{*}$ & $(0.154)$ & 0.761 \\
\hline Log value durable assets 2018 & 0.067 & $(0.183)$ & 1.069 & 0.066 & $(0.148)$ & 1.068 & -0.093 & $(0.116)$ & 0.912 \\
\hline Log value durable assets 2007 & $-0.493^{\star}$ & (0.288) & 0.611 & 0.123 & $(0.206)$ & 1.131 & $-0.357^{\star \star}$ & $(0.165)$ & 0.700 \\
\hline FISP beneficiary 2018 (0/1) & -1.538 & $(1.220)$ & 0.215 & -1.070 & $(0.736)$ & 0.343 & -0.017 & $(0.461)$ & 0.984 \\
\hline FISP beneficiary 2007(0/1) & -0.205 & (0.523) & 0.815 & -0.295 & (0.394) & 0.744 & 0.301 & (0.308) & 1.352 \\
\hline Obtained credit 2018 (0/1) & -0.258 & $(0.918)$ & 0.773 & -0.241 & $(0.639)$ & 0.786 & -0.162 & $(0.471)$ & 0.851 \\
\hline Obtained credit 2007 (0/1) & 0.326 & (0.593) & 1.385 & -0.255 & (0.495) & 0.775 & 0.173 & $(0.366)$ & 1.189 \\
\hline Received any extension 2018 (0/1) & 0.957 & $(0.662)$ & 2.603 & 0.763 & $(0.585)$ & 2.144 & $0.825^{\star}$ & $(0.457)$ & 2.282 \\
\hline Received any extension 2007 (0/1) & 0.661 & $(0.640)$ & 1.937 & 0.580 & $(0.489)$ & 1.787 & -0.242 & (0.383) & 0.785 \\
\hline Lead farmer in community $(0 / 1)$ & -0.437 & $(0.535)$ & 0.646 & -0.421 & $(0.398)$ & 0.657 & 0.070 & $(0.313)$ & 1.073 \\
\hline HH has club member $2018(0 / 1)$ & -1.719 & $(1.149)$ & 0.179 & -0.702 & $(0.582)$ & 0.496 & -0.273 & $(0.426)$ & 0.761 \\
\hline Commercialisation Index 2018 & $-0.024^{\star \star \star}$ & $(0.007)$ & 0.976 & $0.011^{*}$ & $(0.006)$ & 1.011 & -0.002 & $(0.005)$ & 0.998 \\
\hline Commercilisation Index 2007 & -0.004 & (0.008) & 0.996 & $0.015^{\star \star \star}$ & $(0.006)$ & 1.015 & 0.007 & $(0.004)$ & 1.007 \\
\hline Residence in Mchinji (0/1) & -0.500 & $(0.536)$ & 0.607 & -0.569 & $(0.452)$ & 0.566 & $0.888^{\star \star \star}$ & $(0.331)$ & 2.430 \\
\hline Original $\mathrm{HH}(0 / 1)$ & 0.639 & $(0.770)$ & 1.895 & -0.262 & $(0.636)$ & 0.769 & -0.056 & $(0.511)$ & 0.945 \\
\hline Constant & -1.239 & (2.409) & 0.290 & -0.394 & (2.068) & 0.674 & -2.226 & (1.620) & 0.108 \\
\hline
\end{tabular}

Notes: The base line is the 'stepping-in' category. RRR is the relative risk ratio reporting the exponential of the coefficient $-\exp (b)$. The RRR = 1 implies no difference /little difference in risk (incidence in each group is the same); $R R R>1$ means risk of particular livelihood trajectory is increased by exposure; $R R R<1$ implies risk of particular livelihood trajectory is decreased by exposure. Coefficient interpretation: in comparison to the base category (stepping in), variable $\mathrm{x}$ is associated with a lower/higher (depending on the sign of the coefficient) likelihood of being in a certain livelihood trajectory. Standard errors in parentheses. ${ }^{*} p<0.10,{ }^{\star \star} p<0.05,{ }^{* \star} p<0.01$.

Source: Authors' own.

\subsection{Determinants of livelihood trajectories}

In Table 5.3, multinomial logit estimates of livelihood trajectories are presented. The coefficient reported is interpreted relative to the base category, such that an independent variable $\mathrm{x}$ is associated with $\mathrm{a}$ lower/higher likelihood of being in a certain livelihood trajectory (depending on the sign of the coefficient). We are not able to interpret the magnitude of the coefficient itself. For instance, in comparison to stepping in, results indicate a higher likelihood of the steppingup trajectory being associated with household heads being married. There is also the inclusion of a relative 
risk ratio $(R R R)$ where an $R R R$ equal to one implies no difference (incidence of each livelihood trajectory group is the same); an RRR greater than one means that the risk of a particular livelihood trajectory is increased by exposure; an RRR less than one implies that the risk of a particular livelihood trajectory is decreased by exposure with the magnitude obtained. For example, being married increases the odds of being in a stepping-up trajectory relative to stepping in by 5.5 times.

Furthermore, households that step up are associated with significantly higher commercialisation experiences in the current year (2018) and initial year of 2007. However, stepping up is significantly constrained by years of education, labour availability, and number of crops cultivated. Relative to households that step in, higher years of education in a household are associated with a lower likelihood of stepping-up agricultural livelihoods. Likewise, households that hired labour in 2018 are less likely to belong to the stepping-up group. Further, the more crops a household cultivated, the less was the likelihood of stepping up in comparison to the base category.

Compared to households in the stepping-in category, we find that hiring of agricultural labour in 2007 is associated with a higher likelihood of dropping out of agriculture. However, a higher number of livestock units in 2018, more crops cultivated in 2018, and a greater extent of commercialisation are associated with a lower possibility of dropping out. For the hanging-in category, results show that, relative to the stepping-in category, the more land a household had in 2007, the more likely they are to hang in their agricultural livelihood. Again, being in receipt of extension services in 2018 and being resident in Mchinji District is associated with a higher likelihood of hanging in. On the contrary, the more crops cultivated, the less the chance is of hanging in agricultural livelihoods. Initial conditions also mattered, with the likelihood of hanging in being lower for households with more durable assets at baseline in 2007.

Unlike the coefficients and RRR results which are reported with reference to the base category, marginal effects can be obtained for all livelihood trajectories (summing to zero). The margins can also be interpreted as a unit change in $\mathrm{x}$ resulting in a particular trajectory being less or more likely depending on the associated sign of the margin. Table 5.4 presents marginal effects for the different livelihood trajectories. In terms of the extent of crop marketing, results indicate that an increase in household commercialisation made dropping out less likely in 2018, and increased the stepping-up trajectory by 0.2 percentage points. Initial market engagement in 2007 tends to provide an impetus for the stepping-up category (by 1 per cent) but reduces the chances of stepping in by 2 per cent. The observed reduction of the stepping-in category odds may be explained by the tendency of households that do well in commercialisation to invest the proceeds in the education of the children who are less likely to take up agricultural livelihoods.

Whilst commercialisation is important for livelihood pathways, the margins realised are very small. This is more vivid when illustrated with predicted marginal effects plots as shown in Appendix Figure A3. Whilst the odds of dropping out decline with increasing commercialisation, the odds of hanging in appear the same, irrespective of the level of commercialisation. The odds of stepping up increase with increasing commercialisation but the increase looks more with initial commercialisation in 2007 than current levels in 2018. The graphs further show that the steppingin category declines with increasing commercialisation in 2007 but remains largely constant with commercialisation in 2018. This may well reflect the levels of farmer integration in markets which remain weak, exploitative, and rudimentary in providing sustained poverty escapes in Malawi.

We find the maximum years of education in a household are significantly associated with the stepping-up livelihood trajectories. An additional year of education in the household is associated with a stepping-up trajectory being 2.3 per cent less likely. In contrast, for stepping-in households, there is the opposite effect, possibly reflecting a scarcity of formal jobs and startup capital for enterprises, especially among the youth.

Regarding the use of hired agricultural labour, whilst important for expanding agricultural activities, we find that it is less likely to be used among households that are stepping up and stepping into agriculture. Significantly, this reduces the odds of households moving into the stepping-up livelihood trajectories by 12.5 per cent which is contrary to our expectation that households stepping up may require more labour that could be sourced on the market. This may well reflect the high costs of hiring agricultural labour: Dimowa, Michaelowa and Weber (2010) find that the supply of ganyu labour rises with increasing wages which may stifle demand, especially in this setting where incomes are seasonal. The hiring of labour among the original households in 2007 does not provide an impetus for continuity of the practice later but significantly reduces the possibility of stepping in agricultural livelihoods by 14.3 per cent. 
Table 5.4 Determinants of livelihood trajectories (marginal effects reported)

\begin{tabular}{|c|c|c|c|c|}
\hline & Dropping out & Stepping up & Hanging in & Stepping in \\
\hline Male-headed household (0/1) & -0.054 & $(0.754)$ & 0.116 & -0.004 \\
\hline Age in years of $\mathrm{HH}$ head & $0.002^{*}$ & $(0.020)$ & 0.001 & -0.002 \\
\hline $\mathrm{HH}$ is married $(0 / 1)$ & -0.003 & $(0.895)$ & 0.034 & $-0.195^{\star}$ \\
\hline Max. years of $\mathrm{HH}$ education & -0.003 & $(0.067)$ & 0.012 & $0.014^{*}$ \\
\hline Adult equivalents 2018 & 0.011 & $(0.140)$ & -0.014 & -0.004 \\
\hline Adult equivalents 2007 & 0.005 & $(0.127)$ & 0.010 & -0.010 \\
\hline Hired labour 2018 (0/1) & 0.042 & $(0.584)$ & 0.074 & 0.008 \\
\hline Hired labour 2007 (0/1) & $0.077^{\star}$ & $(0.588)$ & 0.055 & $-0.143^{\star \star}$ \\
\hline Total livestock units 2018 & $-0.081^{*}$ & (0.598) & 0.008 & 0.039 \\
\hline Total livestock units 2007 & 0.006 & $(0.236)$ & $0.031^{*}$ & -0.005 \\
\hline Log land 2018 & 0.034 & $(0.619)$ & -0.070 & 0.045 \\
\hline Log land 2007 & -0.004 & $(0.636)$ & 0.096 & $-0.123^{\star}$ \\
\hline No. of crops cultivated 2018 & $-0.048^{\star \star \star}$ & $(0.205)$ & $0.041^{\star \star}$ & 0.020 \\
\hline No. of crops cultivated 2007 & 0.013 & $(0.237)$ & -0.024 & $0.069^{\star \star}$ \\
\hline Log value durable assets 2018 & 0.007 & $(0.183)$ & -0.023 & 0.005 \\
\hline Log value durable assets 2007 & -0.028 & $(0.288)$ & $-0.061^{\star \star}$ & $0.051^{\star}$ \\
\hline FISP beneficiary 2018 (0/1) & -0.099 & -0.104 & 0.092 & 0.111 \\
\hline FISP beneficiary 2007(0/1) & -0.020 & -0.046 & 0.078 & -0.013 \\
\hline Obtained credit 2018 (0/1) & -0.011 & -0.017 & -0.013 & 0.041 \\
\hline Obtained credit 2007 (0/1) & 0.023 & -0.043 & 0.036 & -0.016 \\
\hline Received any extension $2018(0 / 1)$ & 0.036 & 0.039 & 0.098 & $-0.172^{\star \star}$ \\
\hline Received any extension 2007 (0/1) & 0.048 & 0.070 & -0.093 & -0.025 \\
\hline Lead farmer in community (0/1) & -0.029 & -0.047 & 0.046 & 0.029 \\
\hline HH has club member $2018(0 / 1)$ & -0.110 & -0.046 & 0.030 & 0.126 \\
\hline Commercialisation Index 2018 & $-0.002^{\star \star \star}$ & $0.002^{\star \star \star}$ & -0.000 & 0.000 \\
\hline Commercialisation Index 2007 & -0.001 & $0.001^{\star \star}$ & 0.001 & $-0.002^{*}$ \\
\hline Residence in Mchinji (0/1) & -0.055 & $-0.101^{\star \star}$ & $0.214^{\star \star \star}$ & -0.058 \\
\hline Original $\mathrm{HH}(0 / 1)$ & 0.053 & -0.038 & -0.018 & 0.002 \\
\hline Pseudo R-squared & 0.1777 & & & \\
\hline Probability > Chi-squared & 0.0000 & & & \\
\hline Log likelihood - Ratio Chi-squared & 162.90 & & & \\
\hline Number of observations & 358 & & & \\
\hline
\end{tabular}

Notes: Table 5.4 shows marginal effects for different livelihood trajectories. Stepping in was used as the base category in the model estimation. Households in the stepping-out category were removed from the analysis due to small sample size. $(0 / 1)$ indicates dichotomous variables for the stated category equal to 1 , otherwise equal to 0 for the base category. Standard errors in parentheses. ${ }^{*} p<0.10,{ }^{* *} p<0.05,{ }^{* \star *} p<0.01$. A Hausman test of independence of irrelevant alternatives (IIA) shows that the odds are independent of other alternatives. An alternative parsimonious specification with variables that were significant after a Wald test for independent variables is presented in Appendix Table A3. The results obtained show consistent findings for significant variables.

Source: Authors' own

Furthermore, results show that higher livestock ownership in 2018 is associated with a higher likelihood of stepping-up agricultural activities (by 3.5 per cent) while declining levels relate to households dropping out of agriculture. Initial livestock ownership significantly increased the odds of falling into the hanging-in category, helping households to merely make ends meet. Land remains the most important productive resources for agriculture. However, we find its ownership in 2018 does not affect placement 
into any livelihood trajectory. Nonetheless, initial landholding by the original households in 2007 is important, specifically for reducing the odds of stepping into agriculture by about 12. 3 per cent.

With respect to durable asset ownership and accumulation over time, the results show no significant relationship between 2018 status and livelihood paths. There is, however, a significant relationship with the initial 2007 condition, with the odds of stepping up and stepping in increasing by 3.8 and 5.1 per cent, respectively. Further, a unit increase in value of initial durable assets makes hanging in less likely by 6.1 per cent, emphasising the positive role of assets in livelihoods. Sabates-Wheeler et al. (2018) also found that initial land and assets were important livelihood improvements within social protection programmes in Rwanda. Similarly, Mushongah and Scoones (2012) show that asset accumulation and land are important for livelihoods in Zimbabwe.

The number of crops cultivated by households have increased on average over time, with strategies promoting crop diversification such as the Malawi FISP (Kankwamba, Kadzamira and Pauw 2018). We find in 2018 that a unit increase in crops cultivated reduces the possibilities of the dropping-out trajectory by 4.8 per cent, possibly because households benefit from a wide variety of opportunities offered by different crops in terms of production, consumption, and marketing performance, apart from aiding adaptation to climate change (Dillon, McGee and Oseni 2015; Kankwamba et al. 2018; Mertz et al. 2009; Tongruksawattana 2014).

At the same time, increasing the number of crops cultivated significantly increased placement into the hanging-in trajectory by 4.1 per cent. It is likely that such increases in the number of crops cultivated fails to match household production capacity, locking those households into a low input use and low output vicious circle (Chirwa and Dorward 2013; Dorward 2009; Dorward and Chirwa 2011), which is persistent in this setting where poverty is entrenched. There is also the argument that with increasing the number of cultivated crops, households may fail to benefit from efficiency gains that come with specialisation. The initial number of crops cultivated in 2007, on the other hand, is found to significantly reduce placement in stepping-up trajectories by 5.8 per cent but makes stepping in more likely by 6.9 per cent. We suspect that a household stepping into agriculture would have gained prior experience with a variety of crops, making it feasible to venture into this enterprise.

Being in receipt of agricultural extension services in 2018 reduced the likelihood of having a household being placed in the stepping-in trajectory by 17.2 per cent. Those stepping into agriculture are among the young households' heads, with about 60 per cent aged between 19 and 39 years. These individuals, according to Ragasa and Niu (2017) are often excluded from agricultural extension services in Malawi and where they do receive them, tend to receive less services. However, their participation in farmer groups could leverage that but this variable is insignificant. Further, initial extension services in 2007 do not matter for current livelihood trajectories, possibly due to the dynamic nature of agriculture and emerging threats which require continual adaptation and the uptake of new skills to deal with challenges.

There are also significant location differences in terms of livelihood trajectories. Hanging-in households are 21.4 per cent more likely to be found in Mchinji District relative to Ntchisi. In addition, stepping up is 10.1 per cent less likely in Mchinji District, emphasising the role of location-specific effects which mediate access to infrastructure services and linkages to markets in livelihood trajectories of households over time. There were no differences between the original and branching-off households in terms of realised livelihood trajectory paths. Other variables including participation in government large-scale farm input subsidy programmes, ${ }^{3}$ being in receipt of credit, and the presence of a lead farmer in the community were found to be insignificant for livelihood pathways. 


\section{DISCUSSION AND CONCLUDING REMARKS}

In this paper, we determined factors that affect livelihood trajectories using longitudinal tracker quantitative survey data spanning ten years and collected in Ntchisi and Mchinji districts in rural Malawi. We contribute to data collection and methods to operationalise Dorward's (2009) framework on livelihood pathways by categorising households into different trajectories. Several variables are used to categorise households into livelihood trajectories including the proportional change in share of agricultural income between 2007 and 2018, level of income source diversification, and investments in agriculture undertaken by a household. Further consideration is made of participation in social assistance programmes.

Stepping-out households are households whose main income source is either salary or business enterprise. Households that are stepping up their agriculture tend to diversify their income sources and expand investments in agriculture, signified by positive proportional change in income from agriculture between the two survey periods. Hanging in is associated with stagnation in agricultural income, whilst dropping-out households obtain a significant proportion of their income from other sources, including being on social protection programmes. We added the trajectory of stepping in agriculture to capture new farming households that never registered agricultural income at baseline in 2007.

As recognised by many studies before this (Alkire and Santos 2014; Carter and Barrett 2006), the use of arbitrary cut-offs and thresholds is contentious. This assessment makes use of proportional change in agricultural income cut-offs to place households in stepping-up and hanging-in categories. It is possible that in setting the proportional change in agricultural income at more than the 25 per cent used in the present study, many other households would fall under the hanging-in category and not necessarily the stepping-up category. Nonetheless, we adopted a transparent measure that can be replicated and verified in different contexts.

Further, we use this variable in combination with other characteristics of the household, such as income diversification and participation in social assistance programmes, and we therefore account for a set of variables in the placement into livelihood trajectories.
We are also mindful that the absolute income from agriculture may be lower over the years but the proportional change may be the same or higher due perhaps to a considerable decline in other income sources. Another limitation relates to the use of survey income data where respondents may over- or underreport their incomes. We used highly trained research assistants to collect the data and guarded against bias in responses by including checks in the questionnaire to ensure consistency in the data.

Employing descriptive and regression analysis, we find a significant number of households hanging in agricultural livelihoods in Mchinji relative to Ntchisi District, a relatively less developed district. Further, stepping-up agriculture is less likely in Mchinji District, showing that location is a critical factor in livelihood paths taken by households over time. In our analysis, higher maximum years of education in a household is less likely to be found in stepping-up households, reflecting the lower levels of education of the workforce retained in agricultural livelihoods. However, those stepping into agriculture (relatively young in our case) are likely to have higher maximum years of education which demonstrated that agriculture remains the employment choice of many households, including those branching off, even though the challenges of underemployment in agriculture and low returns vis-àvis the education of the workforce remain (Fox, Senbet and Simbanegavi 2016).

This is especially true for the majority of young people who are in transition into the labour market; agriculture offers readily available employment, particularly where cultivatable land is available and inputs are affordable (Jayne, Chamberlin and Headey 2014; Leavy and Hossain 2014). We also find that it is unlikely for stepping-up and stepping-in households to engage hired agricultural labour, commonly called ganyu. Ganyu wages have increased over the years, making it difficult to hire the services. Moreover, because of the continuous provision of low output market prices, farmers tend to lock-in low input use (Dorward and Chirwa 2011) which among other things, limits their demand for agricultural labour in their locality. We further speculate that stepping-in households which are relatively young may have the required labour for 
their agricultural activities, hence the reluctance to engage in such markets.

Livestock is important for livelihoods, both as a source of animal source food and a productive asset that can be sold to smooth consumption and deal with shocks (Azzarri et al. 2014; Dumas et al. 2018; Gao and Mills 2018; Mosites et al. 2015; Papaioannou and Haas 2017). Significantly, a higher number of livestock units in 2018 is observed for stepping-up households and the contrary is observed for those dropping out of agriculture as expected. However, initial livestock ownership increases the category of hanging-in households. It could be because in this context, households tend to have fewer numbers of small ruminants, therefore reducing the livestock effect on livelihoods as shown elsewhere (Dumas et al. 2018). Moreover, where small ruminants of livestock are used to cope with shocks and food insecurities (Anderson et al. 2018; Zanello, Shankar and Poole 2019), sustaining the number of animals becomes a challenge. The literature further seems to suggest that the influence on livelihood trajectories may well depend on the type of livestock owned, as demonstrated by Azzarri et al. (2014) in the context of food and nutrition security.

Whilst land is key in livelihoods, we find that the amount owned in 2018 does not matter; what matters is the initial stock of land-holding of the original households. This is critical for stepping-in households whose original households may have inadequate land to secure land entitlement for the next generation, thereby affecting livelihood paths. In this setting, land is owned on a customary basis and inherited through the family lineage which has increased land fragmentation and tenure insecurity, and reduced holding sizes (Berge et al. 2014), fuelling difficulties in stepping into agriculture (Jayne et al. 2014; Leavy and Hossain 2014).

At the same time, land markets remain small and weak, though there has been increasing commodification of land over the years. Such land transfers are from the relatively labour-poor to labour-rich households, or from the poorest to better-off households in some fashion of distress land renting-out which tends to widen social differences among households (Chamberlin and Ricker-Gilbert 2015; Deininger, Savastano and Xia 2017). Similarly, asset values in 2007 drive households into stepping-up categories and make it less likely to hang in. Literature is awash with evidence of how assets support livelihoods including food security, coping with shocks, and smoothing consumption in different contexts (Hidrobo et al. 2018; Janvry and Sadoulet 2000). However, the current stock of assets does not determine household placement in any trajectory - what matters is what a household had in the past.
Increasing the number of crops cultivated reduces the possibility of dropping out of agriculture as households benefit in terms of food security, and incomes realised from a wide variety of crop sales (Dillon et al. 2015; Singh et al. 2020). Crop diversity also assists with adaptation to climate change (Mertz et al. 2009; Tongruksawattana 2014). There is evidence of households switching crop land allocation based on the price performance of a crop, and diversity makes it possible to hedge failures in the performance of one crop - in production, consumption, or marketing (Radchenko and Corral 2018). However, increasing the number of crops cultivated increases placement in the hanging-in category. Households hanging in barely survive in their agricultural livelihoods; increasing the number of cultivated crops requires increased investments in terms of inputs as well as skills which they rarely possess, making such households vulnerable to crop failure, amidst inadequate resources which would otherwise be the case if such households specialised.

Increasing the number of crops cultivated in 2007, however, provides the prior experience needed for households stepping into agriculture which eases their entry into the enterprise. In a way, stepping-in households initially exposed to the production of various crops face reduced barriers of entry into agricultural livelihoods. Access to useful extension services in 2018 is important for stepping into agriculture; however, young people are often left out of extension services and receive disproportionately less compared to adult households (Ragasa and Niu 2017).

Commercialisation reduces the possibility of dropping out of agriculture and increases the chances of stepping-up livelihoods, a finding consistent with previous studies. Furthermore, in this setting, initial commercialisation spurs investment in agriculture, making households step up their livelihoods. There is evidence attesting that incomes improve and multidimensional poverty reduces with increasing commercialisation (Ogutu and Qaim 2019), as do other livelihood outcomes on food and nutrition security (Carletto et al. 2017; Radchenko and Corral 2018). However, the finding that some households are hanging in in their livelihoods, irrespective of the extent of commercialisation, is concerning, pointing to its failure to sustainably provide poverty escapes to households. Nonetheless, as households do well with commercialisation, they invest in their children's education which expands opportunities to transition to work, not only in agriculture but also in other sectors of the economy. This implies that the multiplier effects of investing in agriculture, the mainstay of Malawi's economy, may be huge. 
We conclude that factors driving rural livelihood trajectories are not the same for farmers in different pathways. Households dropping out of agriculture tend to have difficulties accumulating livestock assets, engaging with markets, and diversifying their crop production, making reliance on social assistance key. The hanging-in trajectory, on the other hand, is likely among households whose assets are falling from initial stocks, who diversify crop production in an attempt to deal with associated risk, and who maintain their wealth by increasing the number of crops cultivated in the current period. Whilst they enjoyed a positive association with livestock assets in 2007, these conditions are not enough to help them leap forward from the status of just surviving in agriculture.

The stepping-up trajectory is driven by crop commercialisation over time with significant asset accumulation, confirming our hypothesis. Of importance is the stock of current livestock assets and initial durable assets which supports the expansion of agricultural enterprises. The stepping-in trajectory is positively associated with increasing maximum education in the household, experience with the cultivation of a variety of crops at baseline, as well as initial durable assets stock. The importance of initial conditions differs among households placed in different livelihood trajectories. An initial stock of durable assets is important for stepping-up and stepping-in agricultural livelihoods, whilst the initial level of household crop commercialisation drives the stepping-up pathway. However, the stepping-in trajectory is constrained by land-holding sizes but is more likely if a household has had experience with the cultivation of several crops.

These findings suggest that there is scope to increase the number of people stepping up and to reduce those in the hanging-in category, especially in Ntchisi, a least developed district compared to Mchinji. Such an economically less active location may have larger multiplier effects from agriculture investments. However, agriculture itself remains unattractive and returns a workforce with little education which has implications on the transformation agenda for the sector. To be successful, agriculture needs skilled and knowledgeable farmers who can easily assimilate and utilise opportunities that exist in the sector.

The paradox is that even where commercialisation is working, households invest the proceeds in the education of their children who may end up leaving agriculture altogether. Overall, the next generation of farmers who are better off in terms of education will only stay in this sector if there is an increase in its productivity and profitability. Even so, there is a need to ease the challenges in accessing land and other inputs to ease the entry of new farmers into meaningful agriculture. We find that stepping-up households do not hire significant agricultural labour which speaks volumes about the failure of such farmers to create local economy job opportunities, especially in this context where there is little mechanisation.

Interestingly, we found that increasing the number of crops cultivated is associated with less chance of dropping out but at the same time facilitated the hanging in of households in their livelihoods. This implies that the blanket recommendation to farmers to diversify crop production may not deliver the same benefits to all farmers. This may well be complemented with useful extension services, especially for new farming households. Further, our study suggests that initial conditions are a precursor for livelihood pathways. In particular, initial livestock assets tend to increase the possibility of hanging in; initial commercialisation fuels stepping up; initial land-holding reduces the possibility of stepping into agriculture; and initial durable assets increase the likelihood of stepping up and into agriculture livelihoods. Thus, to avoid a 'one-size-fits-all' approach to development, multiple determinants for different livelihood trajectories must be recognised, including context-specific factors that mediate outcomes. 
Abdullah et al. (2019) 'Determinants of Commercialization and its Impact on the Welfare of Smallholder Rice Farmers by using Heckman's Two-Stage Approach', Journal of the Saudi Society of Agricultural Sciences 18.2: 224-33 (accessed 9 February 2021)

Adger, W.N. et al. (2002) 'Migration, Remittances, Livelihood Trajectories, and Social Resilience', Journal of the Human Environment 31.4: 358-66 (accessed 9 February 2021)

AGRA (2019) Africa Agriculture Status Report 2019. The Hidden Middle: A Quiet Revolution in the Private Sector Driving Agricultural Transformation, Nairobi: Alliance for a Green Revolution in Africa

Alkire, S. and Santos, M.E. (2014) 'Measuring Acute Poverty in the Developing World: Robustness and Scope of the Multidimensional Poverty Index', World Development 59: 251-74 (accessed 9 February 2021)

Anderson, C.L.; Reynolds, T.; Merfeld, J.D. and Biscaye, P. (2018) 'Relating Seasonal Hunger and Prevention and Coping Strategies: A Panel Analysis of Malawian Farm Households', The Journal of Development Studies 54.10: 1737-55 (accessed 9 February 2021)

Azzarri, C.; Cross, E.; Haile, B. and Zezza, A. (2014) Does Livestock Ownership Affect Animal Source Foods Consumption and Child Nutritional Status? Evidence from Rural Uganda, Policy Research Working Paper 7111, Washington DC: World Bank Group

Babulo, B. et al. (2008) 'Household Livelihood Strategies and Forest Dependence in the Highlands of Tigray, Northern Ethiopia', Agricultural Systems 98.2: 147-55 (accessed 9 February 2021)

Bagchi, D.K. et al. (1998) 'Conceptual and Methodological Challenges in the Study of Livelihood Trajectories: Case-Studies in Eastern India and Western Nepal', Journal of International Development 10.4: 453-68

Banerjee, A. et al. (2015) 'A Multifaceted Program Causes Lasting Progress for the Very Poor: Evidence from Six Countries', Science 348. 6236: 1260799 (accessed 9 February 2021)

Barrett, C.B.; Reardon, T. and Webb, P. (2001) 'Nonfarm Income Diversification and Household Livelihood Strategies in Rural Africa: Concepts, Dynamics, and Policy Implications', Food Policy 26.4: 315-31

Berge, E.; Kambewa, D.; Munthali, A. and Wiig, H. (2014) 'Lineage and Land Reforms in Malawi : Do Matrilineal and Patrilineal Landholding Systems Represent a Problem for Land Reforms in Malawi?', Land Use Policy 41: 61-69 (accessed 9 February 2021)

Bernard, T. and Spielman, D.J. (2009) 'Reaching the Rural Poor through Rural Producer Organizations ? A Study of Agricultural Marketing Cooperatives in Ethiopia', Food Policy 34.1: 60-69 (accessed 9 February 2021)

Brown, S.; Ortiz-Nuñez, A. and Taylor, K. (2011) 'What Will I Be When I Grow Up? An Analysis of Childhood Expectations and Career Outcomes', Economics of Education Review 30.3: 493-506 (accessed 9 February 2021)

Brown, D.R.; Stephens, E.C.; Ouma, J.O.; Murithi, F.M. and Barrett, C.B. (2006) 'Livelihood Strategies in the Rural Kenyan Highlands', African Journal of Agriculture and Resource Economics 1.1: 21-36

Carletto, C.; Corral, P. and Guelfi, A. (2017) 'Agricultural Commercialization and Nutrition Revisited: Empirical Evidence from Three African Countries', Food Policy 67: 106-18 (accessed 9 February 2021)

Carletto, G.; Ruel, M.; Winters, P. and Zezza, A. (2015) 'Farm-Level Pathways to Improved Nutritional Status: Introduction to the Special Issue', The Journal of Development Studies 51.8: 945-57 (accessed 9 February 2021) 
Carter, M.R. and Barrett, C.B. (2006) 'The Economics of Poverty Traps and Persistent Poverty: An Asset-Based Approach', The Journal of Development Studies 42.2: 178-99 (accessed 9 February 2021)

Chamberlin, J. and Ricker-Gillbert, J.E. (2015) 'What are the Drivers of Rural Land Rental Markets in Sub-Saharan Africa, and How Do They Impact Household Welfare? Evidence from Malawi and Zambia', paper presented at the International Conference of Agricultural Economists, Milan, 8-14 August

Chirwa, E.W. and Dorward, A. (2013) Agriculture Input Subsidies: The Recent Malawi Experience, Oxford: Oxford University Press

Chirwa, E.W. and Zakeyo, C. (2004) Effects of Economic and Trade Policy Reforms on Food Security in Malawi, Wadonda Consult Working Paper WC/02/04, Zomba: Wadonda Consult (accessed 9 February 2021)

Deininger, K. ; Savastano, S. and Xia, F. (2017) 'Smallholders' Land Access in Sub-Saharan Africa: A New Landscape?', Food Policy 67: 78-92 (accessed 10 February 2021)

Dillon, A.; McGee, K. and Oseni, G. (2015) 'Agricultural Production, Dietary Diversity and Climate Variability', The Journal of Development Studies 51.8: 976-95 (accessed 10 February 2021)

Dimowa, R.; Michaelowa, K. and Weber, A. (2010) Ganyu Labour in Malawi: Understanding Rural Households' Labour Supply Strategies, Proceedings of the German Development Economics Conference, Conference Paper 29, Göttingen: Verein für Socialpolitik, Ausschuss für Entwicklungsländer

Dorward, A. (2009) 'Integrating Contested Aspirations, Processes and Policy: Development as Hanging In, Stepping Up and Stepping Out', Development Policy Review 27.2: 131-46

Dorward, A. and Chirwa, E.W. (2011) 'The Malawi Agricultural Input Subsidy Programme: 2005/06 to 2008/09', International Journal of Agricultural Sustainability 9.1: 232-47 (accessed 10 February 2021)

Dumas, S.E.; Kassa, L.; Young, S.L. and Travis, A.J. (2018) 'Examining the Association between Livestock Ownership Typologies and Child Nutrition in the Luangwa Valley, Zambia', PLOS ONE 13.2: e0191339 (accessed 10 February 2021)

Ellis, F. (2008) 'The Determinants of Rural Livelihood Diversification in Developing Countries', Journal of Agricultural Economics 51.2: 289-302

Ellis, F.; Kutengule, M. and Nyasulu, A. (2003) 'Livelihoods and Rural Poverty Reduction in Malawi', World Development 31.9: 1495-1510 (accessed 10 February 2021)

Fox, L.; Senbet, L.W. and Simbanegavi, W. (2016) 'Youth Employment in Sub-Saharan Africa: Challenges, Constraints and Opportunities', Journal of African Economies 25.suppl_1: i3-i15 (accessed 10 February 2021)

Gao, J. and Mills, B.F. (2018) 'Weather Shocks, Coping Strategies, and Consumption Dynamics in Rural Ethiopia', World Development 101: 268-83 (accessed 10 February 2021)

Giesbert, L. and Schindler, K. (2010) 'Assets, Shocks, and Poverty Traps in Rural Mozambique', World Development 40.8: 1594-1609 (accessed 10 February 2021)

Hidrobo, M.; Hoddinott, J.; Kumar, N. and Olivier, M. (2018) 'Social Protection, Food Security, and Asset Formation', World Development 101: 88-103 (accessed 10 February 2021)

Jansen, H.G.P. et al. (2006) 'Determinants of Income-Earning Strategies and Adoption of Conservation Practices in Hillside Communities in Rural Honduras', Agricultural Systems 88.1: 92-110 (accessed 10 February 2021)

Janvry, A. De and Sadoulet, E. (2000) 'Rural Poverty in Latin America: Determinants and Exit Paths', Food Policy 25.4: 389-409

Jayne, T.S.; Chamberlin, J. and Headey, D.D. (2014) 'Land Pressures, the Evolution of Farming Systems, and Development Strategies in Africa: A Synthesis', Food Policy 48: 1-17 (accessed 10 February 2021)

Jayne, T.S.; Mather, D. and Mghenyi, E. (2010) 'Principal Challenges Confronting Smallholder Agriculture in SubSaharan Africa', World Development 38.10: 1384-98 (accessed 10 February 2021) 
Kankwamba, H.; Kadzamira, M. and Pauw, K. (2018) 'How Diversified is Cropping in Malawi? Patterns, Determinants and Policy Implications', Food Security 10.2: 323-38 (accessed 10 February 2021)

Kilelu, C.W.; Klerkx, L. and Leeuwis, C. (2017) 'Supporting Smallholder Commercialisation by Enhancing Integrated Coordination in Agrifood Value Chains: Experiences with Dairy Hubs in Kenya', Experimental Agriculture 53.2: 269-87 (accessed 10 February 2021)

Leavy, J. and Hossain, N. (2014) Who Wants to Farm? Youth Aspirations, Opportunities and Rising Food Prices, IDS Working Paper 439, Brighton: IDS (accessed 10 February 2021)

Logistics Unit (2017) Final Report on the Implementation of the Farm Inputs Subsidy Programme 2016-17, Lilongwe: Logistics Unit

Matita, M. et al. (2018) A Longitudinal Tracker Study of Groundnuts Commercialisation and Livelihood Trajectories in Malawi, APRA Research Note 1, Brighton: Future Agricultures Consortium (accessed 10 February 2021)

McLean, J.E. (2015) 'Beyond the Pentagon Prison of Sustainable Livelihood Approaches and Towards Livelihood Trajectories Approaches', Asia Pacific Viewpoint 56.3: 380-91 (accessed 10 February 2021)

Mertz, O.; Mbow, C.; Reenberg, A. and Diouf, A. (2009) 'Farmers' Perceptions of Climate Change and Agricultural Adaptation Strategies in Rural Sahel', Environmental Management 43.5: 804-16 (accessed 10 February 2021)

Mosites, E.M. et al. (2015) 'The Relationship between Livestock Ownership and Child Stunting in Three Countries in Eastern Africa Using National Survey Data', PLoS ONE 10.9: e0136686

Mushongah, J. (2009) Rethinking Vulnerability: Livelihood Change in Southern Zimbabwe, 1986-2006, Brighton: University of Sussex

Mushongah, J. and Scoones, I. (2012) 'Livelihood Change in Rural Zimbabwe over 20 Years', The Journal of Development Studies 48.9: 1241-57 (accessed 10 February 2021)

NSO (2014) Malawi Labour Force Survey 2012-2013, Zomba: National Statistical Office

Ogutu, S.O. and Qaim, M. (2019) 'Commercialization of the Small Farm Sector and Multidimensional Poverty', World Development 114: 281-93 (accessed 10 February 2021)

Orr, A.; Mwale, B. and Saiti-Chitsonga, D. (2009) 'Exploring Seasonal Poverty Traps: The "Six-Week Window" in Southern Malawi', The Journal of Development Studies 45.2: 227-55 (accessed 10 February 2021)

Papaioannou, K.J. and Haas, M. de (2017) 'Weather Shocks and Agricultural Commercialization in Colonial Tropical Africa: Did Cash Crops Alleviate Social Distress ?', World Development 94: 346-65 (accessed 10 February 2021)

Paudel, U.; Khatri, U. and Pant, K.P. (2018) 'Understanding the Determinants of Household Cooking Fuel Choice in Afghanistan: A Multinomial Logit Estimation', Energy 156: 56-62 (accessed 10 February 2021)

Pritchard, B.;Vicol, M. and Jones, R. (2017) 'How Does the Ownership of Land Affect Household Livelihood Pathways Under Conditions of Deagrarianization? "Hanging In", "Stepping Up" and "Stepping Out" in Two North Indian Villages', Singapore Journal of Tropical Geography 38.1: 41-57 (accessed 10 February 2021)

Radchenko, N. and Corral, P. (2018) 'Agricultural Commercialisation and Food Security in Rural Economies: Malawian Experience', The Journal of Development Studies 54.2: 256-70 (accessed 10 February 2021)

Ragasa, C. and Niu, C. (2017) The State of Agricultural Extension and Advisory Services Provision in Malawi, Technical Report, Washington DC: International Food Policy Research Institute

Rahman, S. and Akter, S. (2014) 'Determinants of Livelihood Choices: An Empirical Analysis from Rural Bangladesh', Journal of South Asian Development 9.3: 287-308 (accessed 10 February 2021)

Sabates-Wheeler, R.; Sabates, R. and Devereux, S. (2018) 'Enabling Graduation for Whom? Identifying and Explaining Heterogeneity in Livelihood Trajectories Post-Cash Transfer Exposure', Journal of International Development 30.7: 1071-95 (accessed 10 February 2021) 
Scoones, I. (2009) 'Livelihoods Perspectives and Rural Development', The Journal of Peasant Studies 36.1: 171-96 (accessed 10 February 2021)

Scoones, I. (1998) Sustainable Rural Livelihoods: A Framework for Analysis, IDS Working Paper 72, Brighton: Institute of Development Studies (accessed 10 February 2021)

Singh, S.; Jones, A.D.; DeFries, R.S. and Jain, M. (2020) 'The Association Between Crop and Income Diversity and Farmer Intra-Household Dietary Diversity in India', Food Security 12: 369-90 (accessed 10 February 2021)

Thomas, D. et al. (2012) 'Cutting the Costs of Attrition: Results from the Indonesia Family Life Survey', Journal of Development Economics 98.1: 108-23 (accessed 10 February 2021)

Tongruksawattana, S. (2014) Climate Shocks and Choice of Adaptation Strategy for Kenyan Maize-Legume Farmers: Insights from Poverty, Food Security and Gender Perspectives, Socioeconomics Working Paper 11, Texcoco: International Maize and Wheat Improvement Center (CIMMYT)

Wooldridge, J.M. (2011) Econometric Analysis of Cross Section and Panel Data, Cambridge MA and London: MIT Press

Xu, D. et al. (2015) 'Household Livelihood Strategies and Dependence on Agriculture in the Mountainous Settlements in the Three Gorges Reservoir Area, China', Sustainability 7.5: 4850-69

Zanello, G.; Shankar, B. and Poole, N. (2019) 'Buy or Make? Agricultural Production Diversity, Markets and Dietary Diversity in Afghanistan', Food Policy 87: 101731 (accessed 10 February 2021)

Zereyesus, Y.A.; Embaye, W.T.; Tsiboe, F. and Amanor-Boadu, V. (2017) 'Implications of Non-Farm Work to Vulnerability to Food Poverty: Recent Evidence From Northern Ghana', World Development 91: 113-24 (accessed 10 February 2021) 


\section{APPENDIX}

Figure A1 Map of study sites: Mchinji and Ntchisi districts in central Malawi

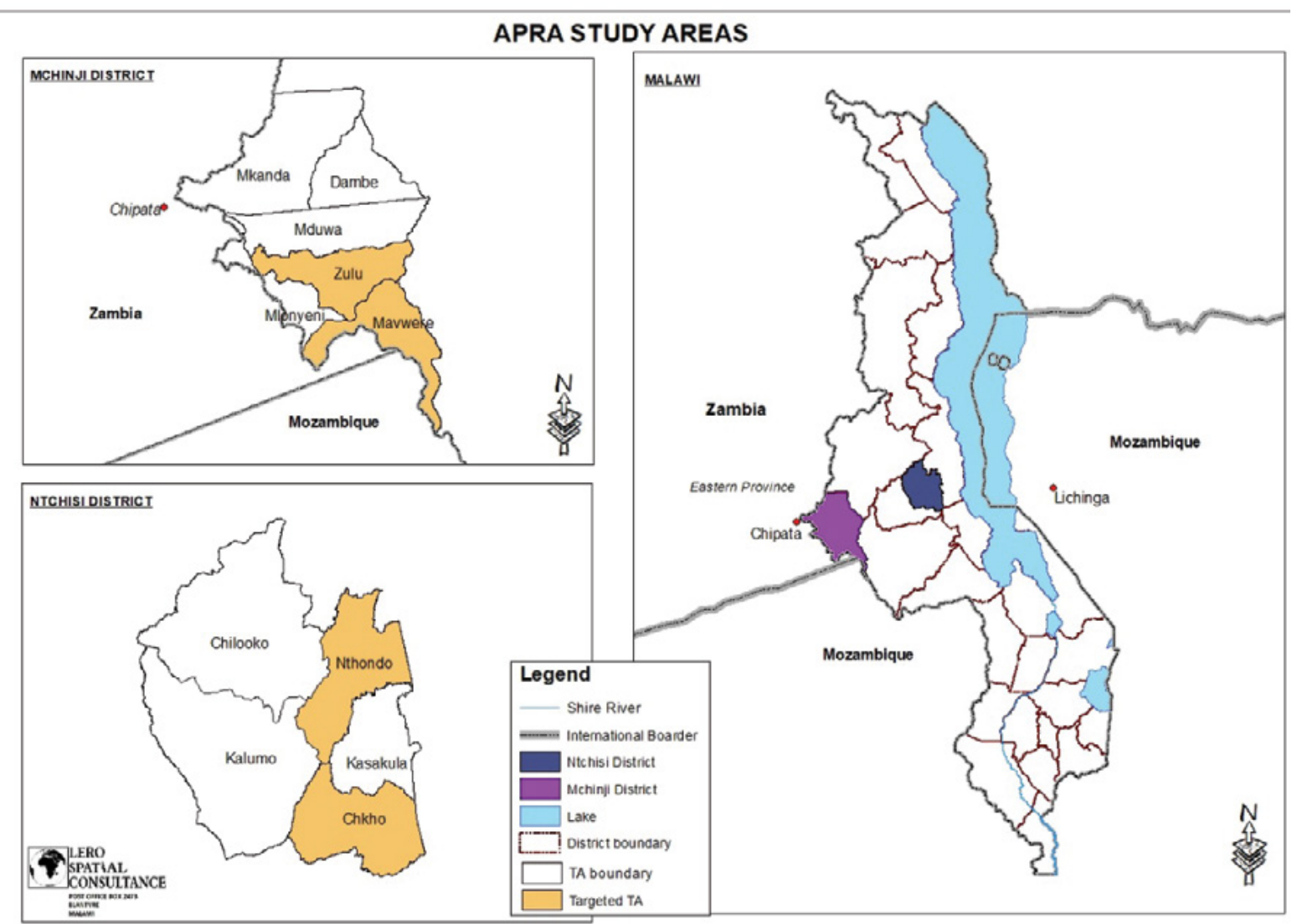

Source: Lero Spatial Consultance (c) Authors

Table A1 Comparing the baseline characteristics of original households (attrition table)

\begin{tabular}{|l|l|l|l|}
\hline \multirow{2}{*}{ Variable } & \multicolumn{2}{|l|}{ Mean values } & P-value \\
\cline { 2 - 4 } & $\begin{array}{l}\text { HH with complete } \\
\text { information }\end{array}$ & Attrite HH & 0.4352 \\
\hline Male-headed HH (O/1) & 0.819 & 0.759 & 0.3544 \\
\hline Age of HH head (years) & 46.810 & 49.931 & 0.0006 \\
\hline HH size (adult equivalents) & 5.075 & 3.664 & 0.9331 \\
\hline Total livestock units (TLU) & 0.715 & 0.751 & 0.4138 \\
\hline Durable assets (US\$) & 142.118 & 285.616 & 0.1576 \\
\hline Land-holding (hectares) & 2.087 & 1.414 & 0.1267 \\
\hline Commercialisation Index & 21.483 & 11.181 & $30 \mathrm{~m}$ \\
\hline Number of observations & 210 & 29 & \\
\hline
\end{tabular}

Source: Authors' own 
Table A2 Description of key variables

\begin{tabular}{|l|l|}
\hline Variable & Description \\
\hline Age of head & Household head age in years \\
\hline Sex of head & $\mathrm{D}=1$ if male-headed household \\
\hline Household size & Adult equivalents \\
\hline Durable assets & Value of durable assets \\
\hline Livestock value & Total livestock units \\
\hline Land-holding & Hectarage of land owned \\
\hline Social infrastructure & $\mathrm{D}=1$ if HH has any member participating in a farmer clubs/organisation \\
\cline { 2 - 2 } & $\mathrm{D}=1$ if received any extension services \\
\hline Subsidies & $\mathrm{D}=1$ If FISP beneficiary, zero otherwise \\
\hline Place of residence & $\mathrm{D}=1$ if Mchinji District, zero otherwise \\
\hline Household status & $\mathrm{D}=1$ if original household, zero otherwise \\
\hline Commercialisation Index & Gross value of crop sales/gross value of crops produced); takes values [0,100] \\
\hline Crop diversification & Number of crops cultivated by household \\
\hline Cropping pattern & $\mathrm{D}=1$ if hired agricultural labour, zero otherwise \\
\hline Access to finance & TD=1 if purchased commercial fertiliser, zero otherwise \\
\hline Original household & $\mathrm{D}=1$ if obtained credit, zero otherwise \\
\hline
\end{tabular}

Source: Authors' own

\section{Figure A2 Predictive marginal effects of commercialisation on livelihood trajectories with $95 \%$ confidence intervals}

Figure A2(a) Predictive marginal effect of 2007 commercialisation level on livelihood trajectories
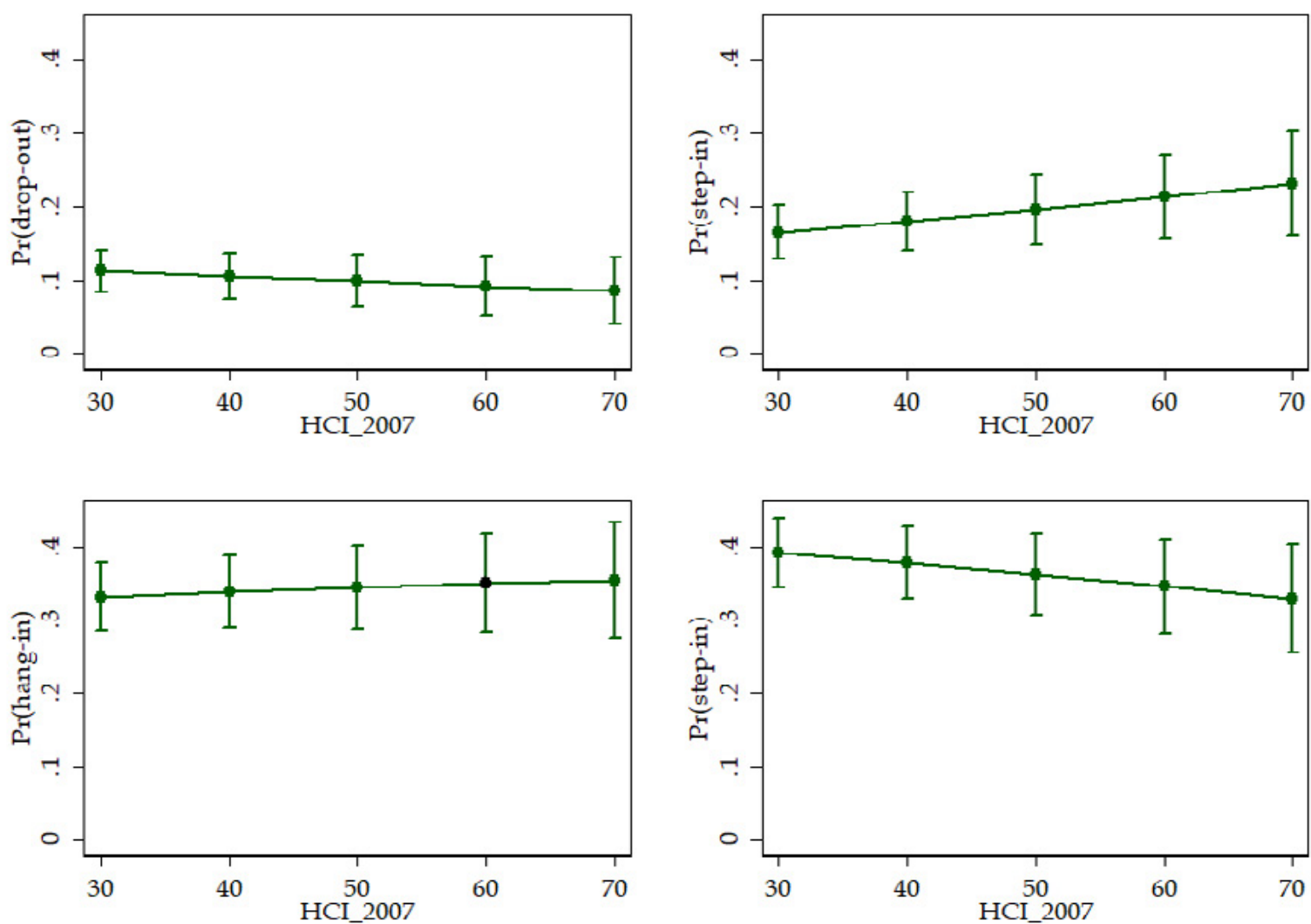

Source: APRA study using USGS, 2018 data 
Figure A2(b) Predictive marginal effect of 2018 commercialisation level on livelihood trajectories
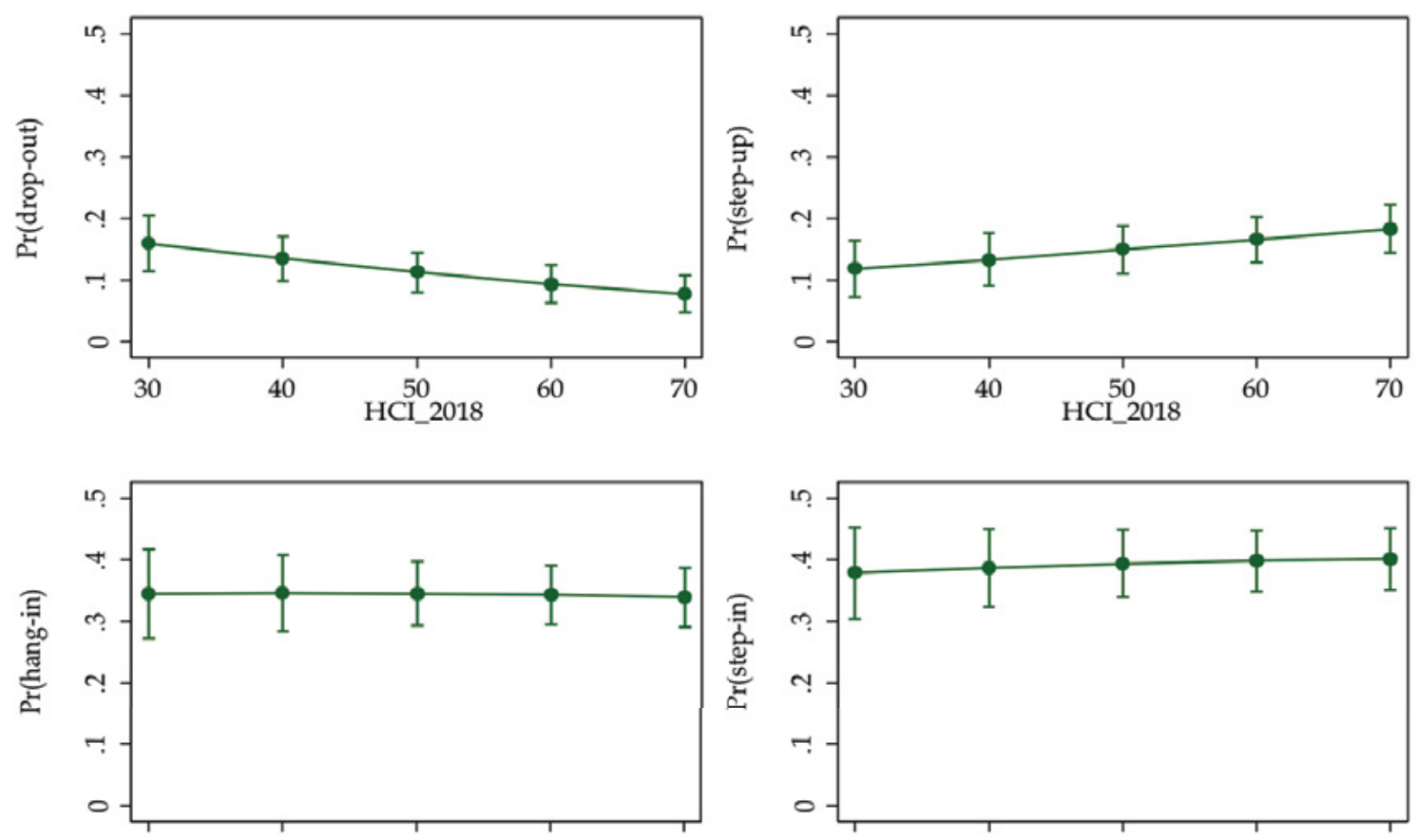

Source: APRA study using USGS, 2018 data

Table A3 Determinants of livelihood trajectories from parsimonious model (marginal effects reported)

\begin{tabular}{|c|c|c|c|c|}
\hline Variable & Dropping out & Stepping up & Hanging in & Stepping in \\
\hline Max. years of education in $\mathrm{HH} 2018$ & -0.003 & $-0.017^{\star \star \star}$ & 0.007 & $0.013^{\star}$ \\
\hline Hired labour $2018(0 / 1)$ & 0.027 & $-0.092^{\star}$ & 0.023 & 0.041 \\
\hline Number of crops cultivated 2018 & $-0.044^{\star \star \star}$ & -0.003 & 0.021 & $0.026^{\star}$ \\
\hline Number of crops cultivated 2007 & 0.018 & $-0.062^{\star \star}$ & 0.006 & 0.037 \\
\hline Log value of durable assets 2007 & -0.012 & 0.011 & -0.019 & 0.020 \\
\hline HH Commercialisation Index 2018 & $-0.002^{\star \star \star}$ & $0.001^{\star \star}$ & -0.000 & 0.001 \\
\hline Commercialisation Index 2007 & $-0.001^{\star \star}$ & $0.002^{\star \star \star}$ & 0.000 & -0.001 \\
\hline Residence in Mchinji (0/1) & -0.040 & $-0.076^{\star}$ & $0.167^{\star \star \star}$ & -0.052 \\
\hline Pseudo R-squared & 0.1008 & & & \\
\hline Probability $>$ Chi-squared & 0.0000 & & & \\
\hline Log likelihood - Ratio Chi-squared & 92.44 & & & \\
\hline Number of observations & 358 & & & \\
\hline
\end{tabular}

Notes: Table A3 shows marginal effects for different livelihood trajectories obtained from a parsimonious model including variables that were significant after a Wald test for independent variables after obtaining estimation results in Table 3 . Obtained results are consistent. Stepping-in was used as the base category in the model estimation. Households in the stepping-out category were removed from analysis due to small sample size. (0/1) indicates dichotomous variables for the stated category equal to 1 , otherwise equal to 0 for the base category. Standard errors in parentheses. ${ }^{*} p<0.10,{ }^{* *} p<$ $0.05,{ }^{* \star *} p<0.01$. A Hausman test of independence of irrelevant alternatives (IIA) shows that the odds are independent of other alternatives.

Source: Authors' own 


\section{ENDNOTES}

1 As of the 2020/21 farming season, the government rebranded the FISP programme the Affordable Inputs Programme (AIP), providing maize seeds and fertiliser as before. However, improved legumes seeds were not available in the AIP programme, likely due to fiscal space since the seed component was financed by development partners who in the current season have not come forward. Instead, other cereal seeds have been added, namely, rice and sorghum. Farmers will further access the inputs using national identification biometric data instead of through the previous approach of issuing coupons.

2 See https://knoema.com/MUER2020/exchange-rates-of-malawian-kwacha-against-major-currencies.

3 For details on the FISP programme, please see Chirwa and Dorward (2013). 
Matita, M. et al. (2021) Determinants of Smallholder Farmers' Livelihood Trajectories: Evidence from Rural Malawi, APRA Working Paper 50, Brighton: Future Agricultures Consortium

(c) APRA 2021

ISBN: 978-1-78118-773-9

DOI: 10.19088/APRA.2021.003

\section{(c) BY-NC-ND}

This is an Open Access report distributed under the terms of the Attribution-Non Commercial-No Derivs 4.0 Unported (CC BY-NC-ND 4.0) Attribution - You must give appropriate credit, provide a link to the license, and indicate if changes were made. You may do so in any reasonable manner, but not in any way that suggests the licensor endorses you or your use. NonCommercial — You may not use the material for commercial purposes. NoDerivatives - If you remix, transform, or build upon the material, you may not distribute the modified material. You are free to: Share - copy and redistribute the material in any medium or format.

https://creativecommons.org/licenses/by-nc-nd/4.0/legalcode

If you use the work, we ask that you reference the APRA website (www.future-agricultures.org/apra/) and send a copy of the work or a link to its use online to the following address for our archive: APRA, Future Agricultures Consortium, University of Sussex, Brighton BN1 9RE, UK (apra@ids.ac.uk)

All APRA Working Papers go through a review process before publication.

\section{Ccreative}

\section{DO YOU HAVE COMMENTS ON THIS PAPER?}

We would welcome your feedback on this working paper!

To provide brief comments, please follow this link to our short APRA Working Paper Feedback form: https://goo.gl/forms/1iVnXhhrlGesfR9

Agricultural Policy Research in Africa (APRA) is a programme of the Future Agricultures Consortium (FAC) which is

generating new evidence and policy-relevant insights on more inclusive pathways to agricultural commercialisation in sub-Saharan Africa. APRA is funded with UK aid from the UK Foreign, Commonwealth \&

Development Office (FCDO) and will run from 2016-2022.

The APRA Directorate is based at the Institute of Development Studies (IDS), UK (www.ids.ac.uk), with regional hubs at the Centre for African Bio-Entrepreneurship (CABE), Kenya, the Institute for Poverty, Land and Agrarian Studies (PLAAS), South Africa, and the University of Ghana, Legon. It builds on more than a decade of research and policy engagement work by the Future Agricultures Consortium (www.future-agricultures.org) and involves more than 100 researchers and communications professionals in Africa, UK, Sweden and USA. 